\title{
An Overview of Transportation in the Nuclear Fuel Cycle
}

by

R. E. Rhoads

May 1977

Prepared for the Energy Research and Development Administration under Contract EY-76-C-06-1830

\section{\%ัต Battelle}




\section{NOTICE}

This report was prepared as an account of work sponsored by the United States Government. Neither the United States nor the Energy Research and Development Administration, nor any of their employees, nor any of their contractors, subcontractors, or their employees, makes any warranty, express or implied, or assumes any legal liability or responsibility for the accuracy, completeness or usefulness of any information, apparatus, product or process disclosed, or represents that its use would not infringe privately owned rights.

\section{PACIFIC NORTHWEST LABORATORY \\ operated by \\ BATTELLE \\ for the}

ENERGY RESEARCH AND DEVELOPMENT ADMINISTRATION

Under Contract EY-76-C-06-1830

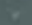

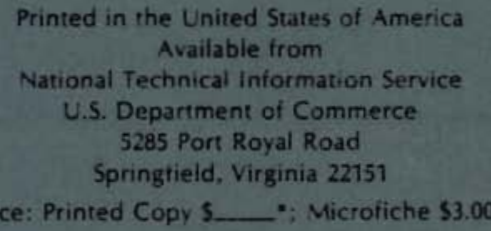

$\begin{array}{cc}\text { *Pages } & \text { NTIS } \\ \text { Selling Price } \\ 001-025 & \$ 4.50 \\ 1226-050 & \$ 5.00 \\ 051-075 & \$ 5.50 \\ 076-100 & \$ 6.00 \\ 107-125 & \$ 6.30 \\ 126-150 & 57.00 \\ 151-175 & 57.75 \\ 176-200 & \$ 8.50 \\ 201-225 & 58.75 \\ 226-250 & \$ 9.00 \\ 251-275 & 5: 0.00 \\ 276-190 & \$ 10.25\end{array}$


BNWL-2066

UC-71

33679000624850

AN OVERVIEW OF TRANSPORTATION

IN THE NUCLEAR FUEL CYCLE

By

R. E. Rhoads

May 1977

BATTELLE

Pacific Northwest Laboratories

Richland, Washington 99352 


\section{PREFACE}

This document was prepared as part of a project to characterize nuclear fuel cycle transportation through the Year 2000 and identify potential difficulties that could develop in the fuel cycle transportation system. The information presented serves as a starting point for that study. The fue 1 cycle description and transportation systems described here have been used as a typical case for the study. It is recognized that future advances in technology and decisions by regulatory agencies and energy policy makers could significantly change the picture presented here. The effect of such changes is being evaluated in other tasks of this study. 


\section{CONTENTS}

PREFACE

1.0 INTRODUCTION

2.0 TRANSPORTATION REGULATIONS

3.0 PACKAGING AND TRANSPORTATION MODES FOR FUEL

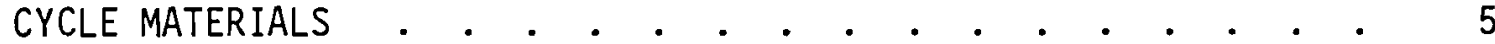

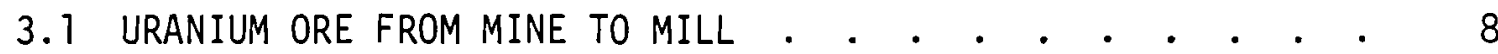

$3.2 U_{3} U_{8}$ FROM MILL TO CONVERSION FACILITY $\quad \cdot \quad \cdot \quad \cdot \quad \cdot \quad \cdot \quad \cdot \quad c \quad 8$

3.3 UF $_{6}$ FROM CONVERSION FACILITY TO GASEOUS

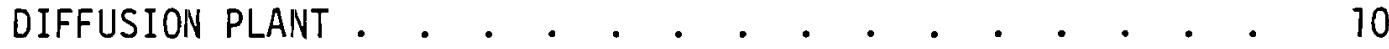

3.4 TRANSPORTATION OF UF 6 FROM GASEOUS DIFFUSION PLANT • • 10

3.4.1 Enriched UF 6 • • • • • • • • • • • • 13

3.4 .2 Depleted UF 6 •

$3.5 \mathrm{UO}_{2}$ TO MANUFACTURERS OF FUEL ELEMENTS $\quad \cdot \quad \cdot \quad \cdot \quad \cdot \quad \cdot \quad \cdot \quad \cdot \quad 15$

3.6 FRESH FUEL ELEMENTS FROM FUEL FABRICATION

3.7 SPENT FUEL ELEMENTS FROM REACTOR TO REPROCESSING PLANT • • 15

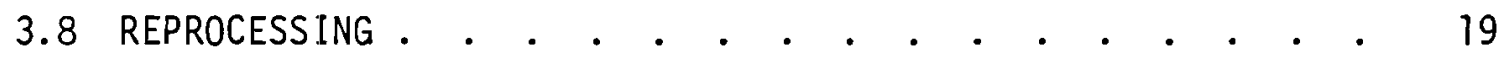

3.8.1 Solidified High Level Waste . . . . . . . . 19

3.8.2 Plutonium . • . • . . . . . . . . . 20

3.8.3 Slightly Enriched UF 6 • • • • • • • • • . 22

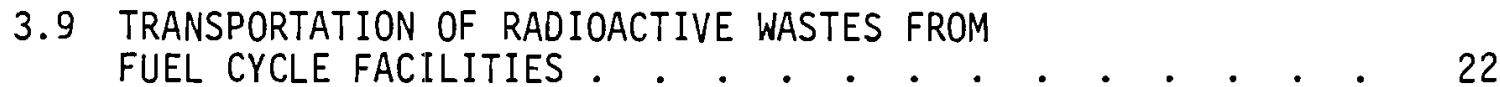

3.9.1 Cladding Hulls . . . . . . . . . . . . . 23

3.9.2 Radioactive ${ }^{85} \mathrm{Kr}$ Gas . . . . . . . . . . 24

3.9.3 Radioactive Iodine . . . . . . . . . . . 24 
3.9.4 Radioactive Tritium Gas . . . . . . . . . . . 24

3.9.5 Low Level Waste . . . . . . . . . . . . . 25

3.9.6 Intermediate Level Waste . . . . . . . . . 26

3.10 IMPORT/EXPORT ACTIVITIES . . . . . . . . . . . . . 28

4.0 TRANSPORTATION SERVICES . . . . . . . . . . . . . . . . . . 29

5.0 PROJECTIONS OF TRANSPORTATION REQUIREMENTS

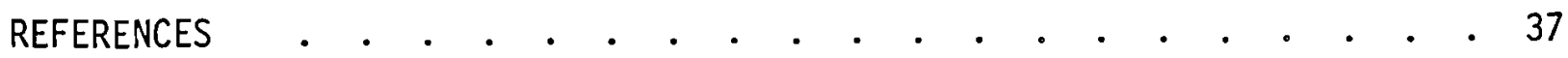

APPENDIX A . . . . . . . . . . . . . . . . . . A-1 


\section{FIGURES}

1 Transportation Steps in the Mixed Oxide Fuel Cycle . . . . 6

2 Reactors and Fuel Cycle Facilities in the U.S. . . . . . 7

3 Possible Domestic Shipping Pathways for $\mathrm{U}_{3} \mathrm{O}_{8}$.

49 Metric Ton UF 6 Cylinders - Rail Transport . . . . . . 11

59 Metric Ton $U_{6}{ }_{6}$ Cylinders - Truck Transport . . . . . . 11

6 Domestic Shipping Pathways for Natural UF 6 • . . . . . . 12

72.3 Metric Ton Uf 6 Cylinders with Overpack . . . . . . . 13

8 Possible Domestic Shipping Pathways for Enriched UF 6 . . . 14

9 Fresh Fuel Shipping . . . . . . . . . . . . 16

10 Spent Fue 1 Cask on Truck Trailer . . . . . . . . 18

11 The IF 300 Spent Fuel Cask on Rail Car . . . . . . . 18

12 High Level Waste Shipping Cask and Railcar. . . . . . 20

13 Radioactive Waste Shipping Cask on Truck Trailer. . . . . 27

\section{$\underline{\text { TABLES }}$}

1 Summary of Information on Projected Shipments of Radioactive Fuel Cycle Materials in the U.S. . . . . . . 33

2 Projected Growth of Nuclear Power . . . . . . . . 34

3 Estimated Annual Shipments from Typical Fuel Cycle Facilities . . . . . . . . . . . . . . 35 


\subsection{INTRODUCTION}

Currently operating and planned facilities associated with the nuclear fuel cycle are situated in diverse geographic locations. Radioactive materials in a wide variety of physical and chemical forms must be transported between these facilities. Materials such as uranium ore concentrate, uranium hexafluoride, fresh fuel, spent fuel, plutonium and many forms of radioactive waste have been shipped routinely in the U.S. for many years. As the fuel cycle is closed and the nuclear industry expands, transportation requirements for these materials will increase substantially. Other materials requiring transportation are expected to be produced in the future (e.g., solidified high level waste, cladding hulls, plutonium with high heat generation rates, radioactive noble gases and spent fuel from LMFBRs). Although this material has not yet been packaged and shipped on a commercial scale, development of appropriate transportation systems is not expected to pose significant technical difficulties.

This document presents a review of current transportation regulations, a description of transportation systems currently in use, a discussion of systems that are anticipated to be developed in the future and a projection of shipments and shipping distances through the Year 2000. Current regulations for transporting radioactive materials are discussed in Section 2.0 and detailed in Appendix A.

Radioactive materials in the nuclear fuel cycle are transported primarily by truck or train. The packaging and transportation modes used for each step of the nuclear fuel cycle are described in Section 3.0. Shipping containers are usually purchased or leased by nuclear fuel cycle facilities and are shipped by common carrier or specialized haulers. A detailed description of these transportation services can be found in Section 4.0.

Section 5.0 summarizes the projected growth of nuclear power, estimated annual shipments of fuel cycle materials and the projected transportation requirements of the nuclear power industry through the Year 2000. 


\subsection{TRANSPORTATION REGULATIONS}

The safety of transportation of radioactive materials is regulated primarily by the U.S. Department of Transportation (DOT) and the Nuclear Regulatory Commission (NRC). (These regulations are summarized in Appendix A.) Their regulations delineate shipping container design requirements, allowable radiation doses and handling procedures for shipments of radioactive material to insure that there are only minimum risks to the public and transportation workers. The major effort in the development of radioactive material shipping containers is the design of a container to efficiently and economically transport material within the framework of these regulations. The physical properties of some fuel cycle materials can pose unique constraints on the design of shipping containers and/or transport modes that comply with transportation regulations. Spent fuel, for example, requires containers with large amounts of radiation shielding and a large heat removal capacity. Shipment quantities must be limited to keep container weights and dimensions within allowable limits for truck and train transport. Shipments containing more than $2 \mathrm{~kg}(4.4 \mathrm{lb})$ of plutonium must be made in special vehicles and under special transport conditions designed to prevent the diversion of fissile radioactive material. 


\subsection{PACKAGING AND TRANSPORTATION MODES \\ FOR FUEL CYCLE MATERIALS}

The principal transport modes for radioactive materials in the nuclear fuel cycle are truck and train. In special cases, shipments by barge have been made. Fuel cycle materials are not routinely shipped by air within the U.S. The majority of radioactive material shipments are presently carried by trucks. They provide a flexible and economic mode for transport of a wide variety of materials. Truck shipments, however, are limited to a maximum payload weight of about 22 metric tons $(48,000 \mathrm{lb})$, without overweight permits. Payloads of 90 metric tons $(200,000$ 1b) or more can be accommodated in train shipments. For shipments in which cask weight is a limiting factor, improved radioactive material-to-shipping container weight ratios can be achieved in train shipments due to the greater size and weight of the shipping containers that can be transported by train.

Figure 1 illustrates the transportation steps in the Light Water Reactor (LWR) fuel cycle using plutonium recycle. It is expected that this fuel cycle will be used extensively in the 1980s and 1990s. The possible introduction of High Temperature Gas-Cooled Reactors (HTGRs) and Liquid Metal Fast Breeder Reactors (LMFBRs) will produce variations in the fuel cycle depicted, but since these reactors are expected to provide only a small percentage of the total nuclear-generated electrical power by the Year 2000, the effect of these variations on transportation requirements wil1 be sma 11 . Figure 2 presents the approximate geographic location of existing and some planned facilities in the nuclear fuel cycle.

The fuel cycle depicted in Figure 1 does not exist today. No commercial reprocessing plants are in operation. Mixed oxide fuel is being fabricated onily for experimental purposes. Commercial-scale facilities for solidifying high level waste (HLW) have not been built. No facilities for storage or disposal of solidifed high level waste or transuranic (TRU) waste have been built. The description of the fuel cycle that follows includes the best available estimates of transportation requirements and transportation systems for a fully-operational fuel cycle using plutonium recycle. 


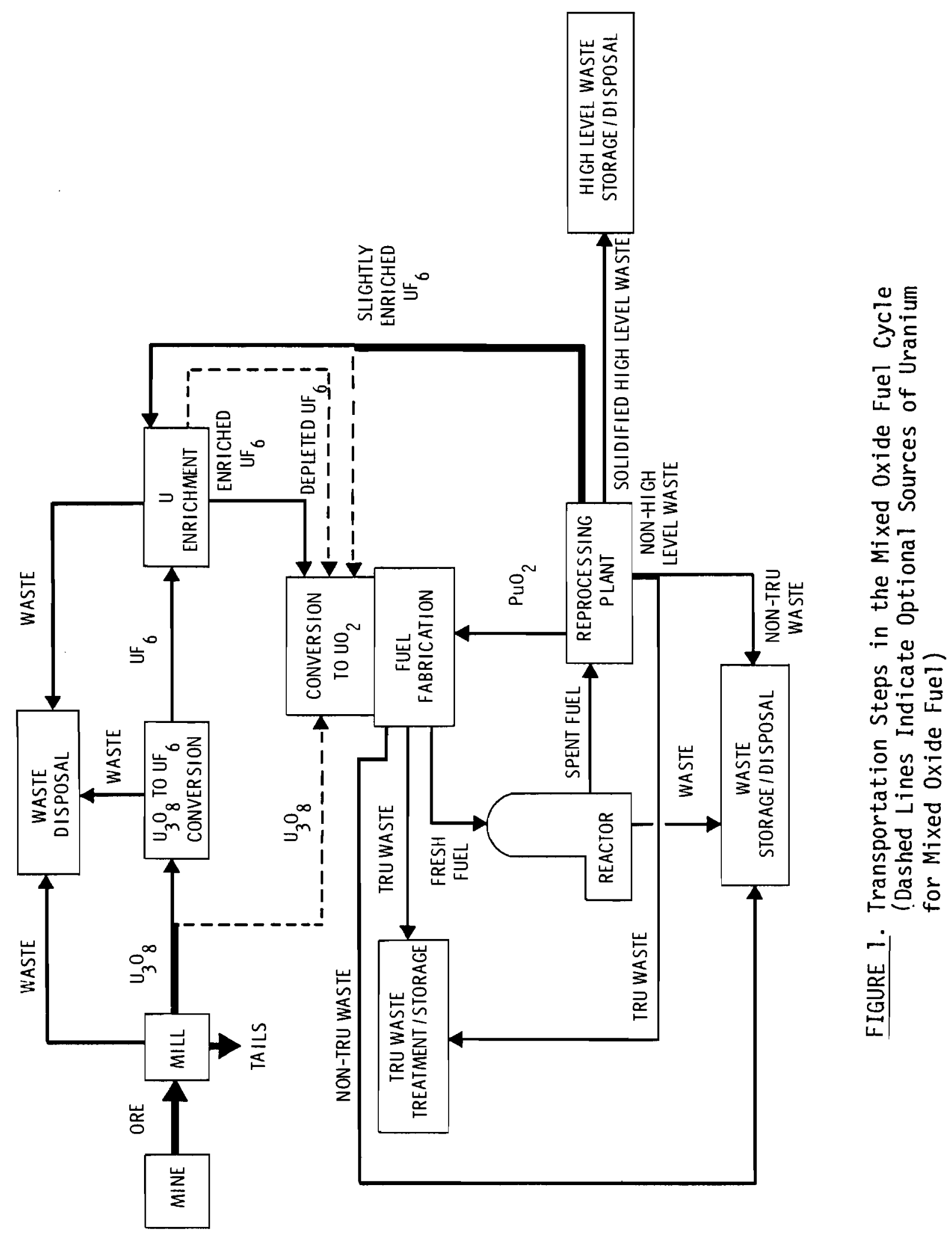




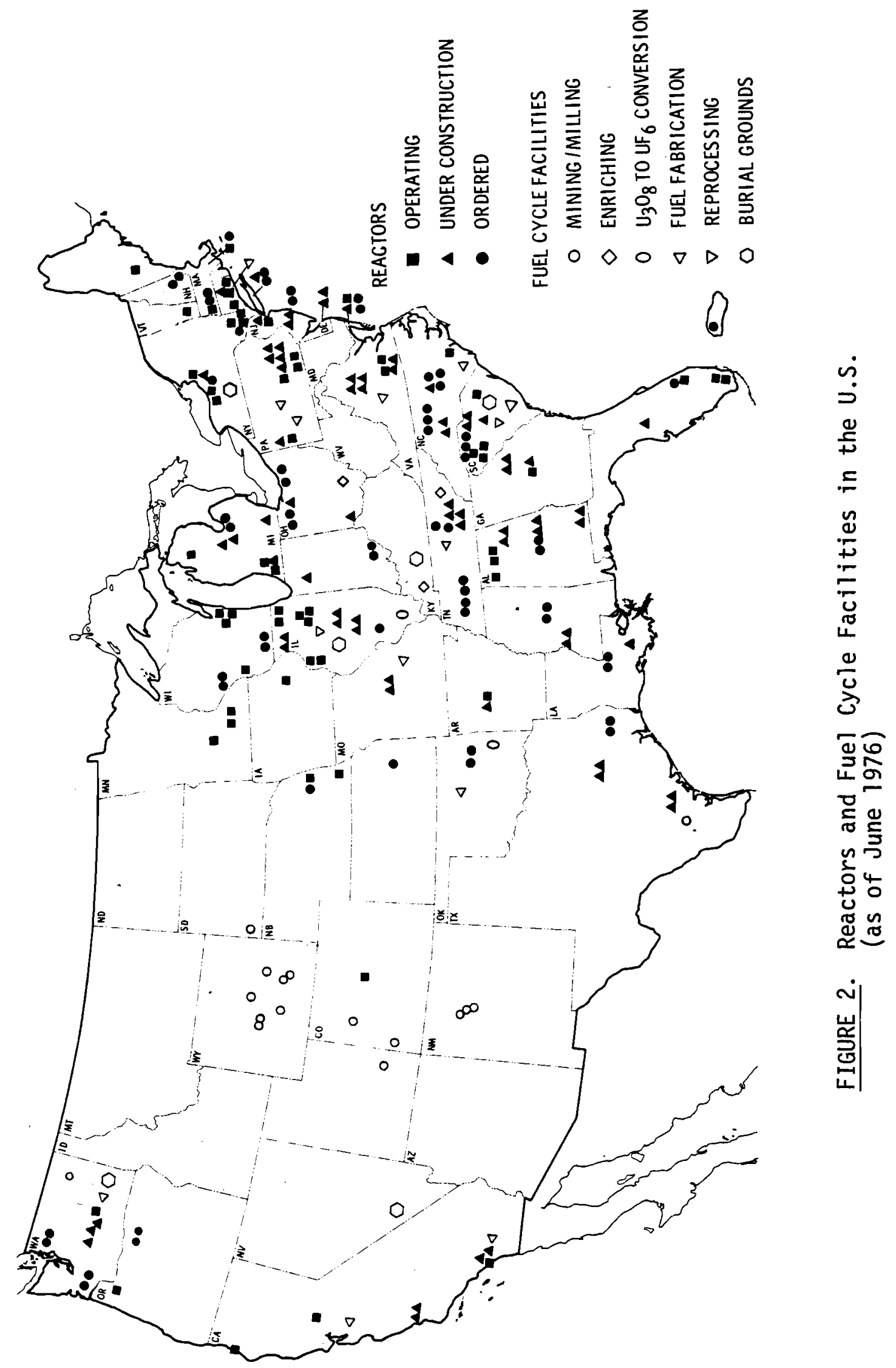




\subsection{URANIUM ORE FROM MINE TO MILL}

The uranium fuel cycle begins with the mining of uranium ore and milling the ore to produce $\mathrm{U}_{3} \mathrm{O}_{8}$ or "yellowcake." Most of the uranium deposits in the U.S. are located in Wyoming, Colorado and New Mexico. Transportation of the ore from the mine to the mills produces only local impacts. Many mills are lcoated at the mine site. The maximum distance for transporting the ore is about $160 \mathrm{~km}$. Uranium ore is designated as "low specific activity" (LSA) material in DOT regulations. It requires no special packaging when transported in an exclusive-use vehicle. (a) Ore is generally delivered to the mill in dump trucks. The trucks may be owned by the mine operator or contracted from local trucking companies.

\section{$3.2 \underline{U}_{3} \underline{0}_{8}$ FROM MILL TO CONVERSION FACILITY}

Uranium ore concentrate $\left(\mathrm{U}_{3} \mathrm{O}_{8}\right)$ is shipped from the uranium mill to the $\mathrm{UF}_{6}$ conversion facility in 210-1iter (55-ga11on) steel drums. Each drum contains about $360 \mathrm{~kg}(800 \mathrm{1b})$ of concentrate. Exclusive-use vehicles are generally employed for these shipments. $\mathrm{U}_{3} \mathrm{O}_{8}$ also qualifies as LSA material. Strong, tight industrial packaging is all that is required to ship this material in exclusive-use vehicles. Rail transport is generally used for $\mathrm{U}_{3} \mathrm{O}_{8}$ shipments. If there is no rail siding at the uranium mill site, the containers of $\mathrm{U}_{3} \mathrm{O}_{8}$ are usually trucked to the nearest rail facility. Fifty-five drums of $\mathrm{U}_{3} \mathrm{O}_{8}$ can be transported in a standard truck van. One hundred ten drum lots are usually shipped in railroad boxcars. There are two $\mathrm{UF}_{6}$ conversion facilities presently in operation, one at Metropolis, Illinois and another at Sequoyah, Oklahoma. Possible shipping paths between the uranium mills and the $\mathrm{UF}_{6}$ conversion facilities are depicted in Figure 3. As indicated in Figure 1, some yellowcake may be shipped directly to the fuel fabricator. This material would be used in the production of natural $\mathrm{UO}_{2}$ to be blended with plutonium for use in mixed oxide fuels for light water reactors or fuel for fast breeder reactors. The amount of material following this pathway is expected to be small through the Year 2000. The tailings produced in the milling operation are disposed of locally. They are usually placed on a tailings pile adjacent to the mill.

\footnotetext{
(a) An exclusive-use vehicle is one carrying no other freight. Exclusive-use vehicles are generally used for radioactive fuel cycle materials.
} 


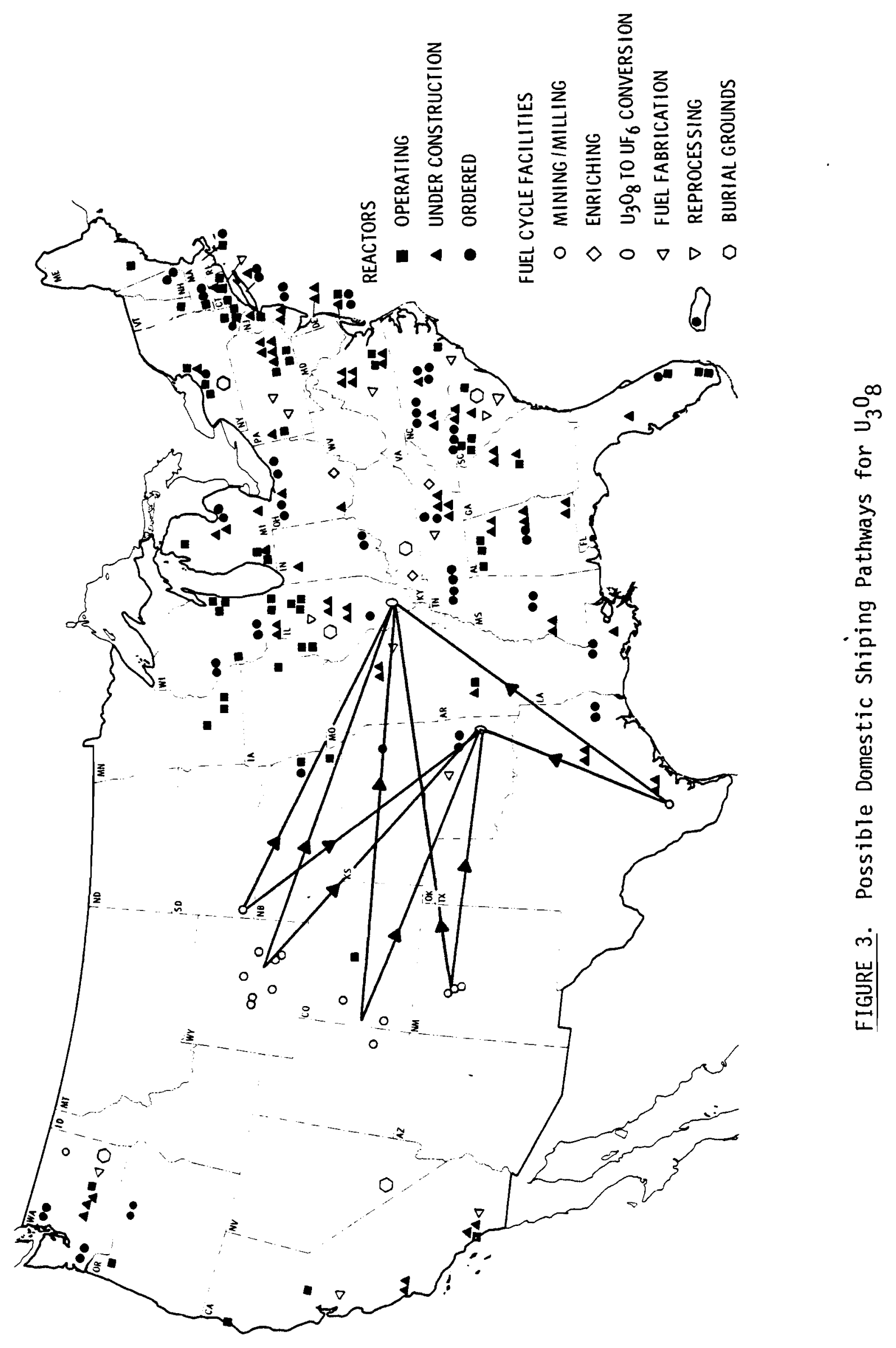




\subsection{UF $_{6}$ FROM CONVERSION FACILITY TO GASEOUS DIFFUSION PLANT}

Uranium hexafluoride is shipped from the $\mathrm{UF}_{6}$ conversion plant to the gaseous diffusion plant where it is enriched to about $3 \%$ in the isotope ${ }^{235} \mathrm{U}$. Natural uranium hexafluoride also qualifies as LSA material. Packaging standards are set by the chemical hazard of the material rather than by its radioactive properties. Natura $1 \mathrm{UF}_{6}$ is shipped 9-metric ton (10-ton) $\mathrm{UF}_{6}$ capacity or 12.6 -metric ton (14-ton) $\mathrm{UF}_{6}$ capacity steel cylinders. The $\mathrm{UF}_{6}$ is placed in the cylinders as a liquid at about $90^{\circ} \mathrm{C}\left(200^{\circ} \mathrm{F}\right)$. It is cooled to room temperature to form a volatile solid before the cylinders are shipped. The cylinders are transported by truck or rail. In the past, rail shipments were used almost exclusively for shipment between the $\mathrm{UF}_{6}$ conversion facilities and the enrichment plants. A change in this practice has been evident recently, so that most shipments are now made by truck. Two 9-metric ton (10-ton) or one 12.7-metric ton (14-ton) cylinder can be transported on a truck trailer of standard construction Four of each type cylinder can be placed on a railroad flatcar. Special cradles and tie-downs are used to secure the cylinders to the transport vehicle. The transport vehicle is usually modified by permanent installation of the cradles and tie-down equipment. A protective device is placed over the filling valve to prevent damage to the valve during handling or transportation operations. Pictures of 9-metric ton $\mathrm{UF}_{6}$ cylinders loaded on a truck trailer and a railroad flatcar are presented in Figures 4 and 5. Possible transportation pathways between the $\mathrm{UF}_{6}$ conversion facilities and the enrichment plants are shown in Figure 6 . The enrichment plants presently in operation are owned by the federal government. They are located at Paducah, Kentucky; Oak Ridge, Tennessee; and Portsmouth, Ohio.

\subsection{TRANSPORTATION OF UF 6 FROM GASEOUS DIFFUSION PLANT}

Two products from the gaseous diffusion plant are enriched $\mathrm{UF}_{6}$ and depleted $U_{6}$. Enriched $U_{6}$ is shipped to a $U_{2}$ conversion plant for use in fabricating reactor fuels. Depleted $U F_{6}$ is presently stored onsite at the diffusion plant. It may eventually be shipped to a fuel fabrication facility. 


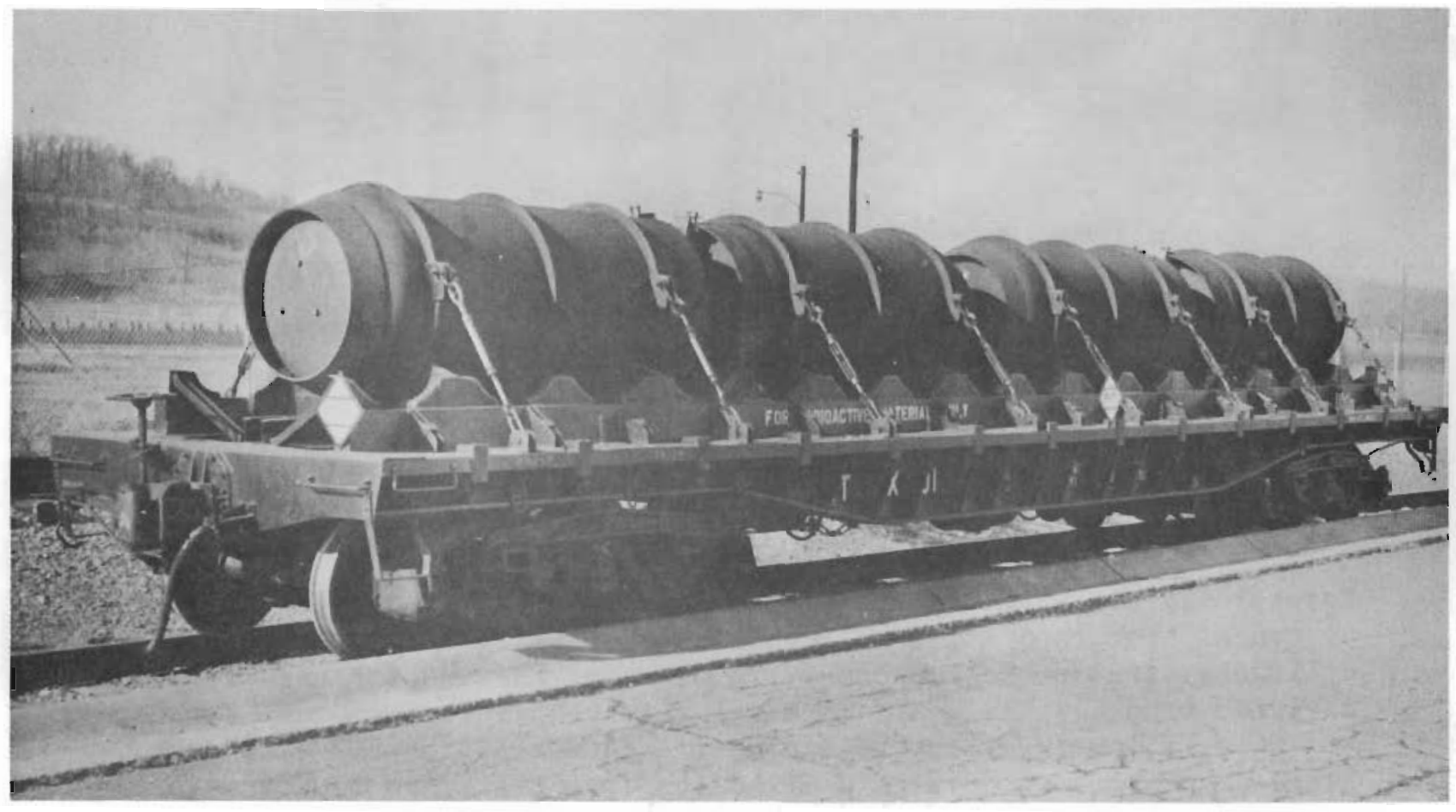

FIGURE 4. 9-Metric Ton UF 6 Cylinders - Rail Transport (1)

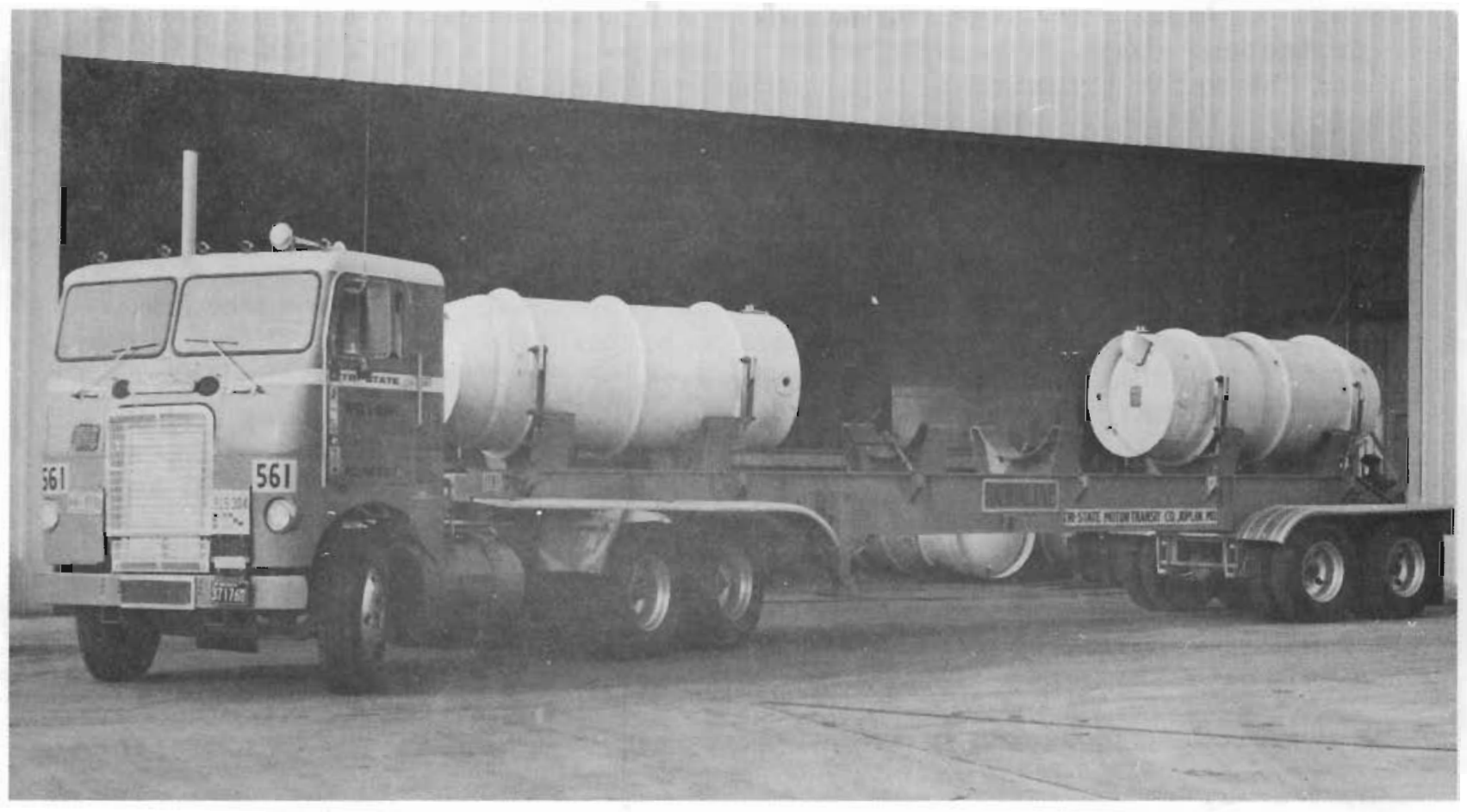

FIGURE 5. 9-Metric Ton UF 6 Cylinders - Truck Transport (1) 


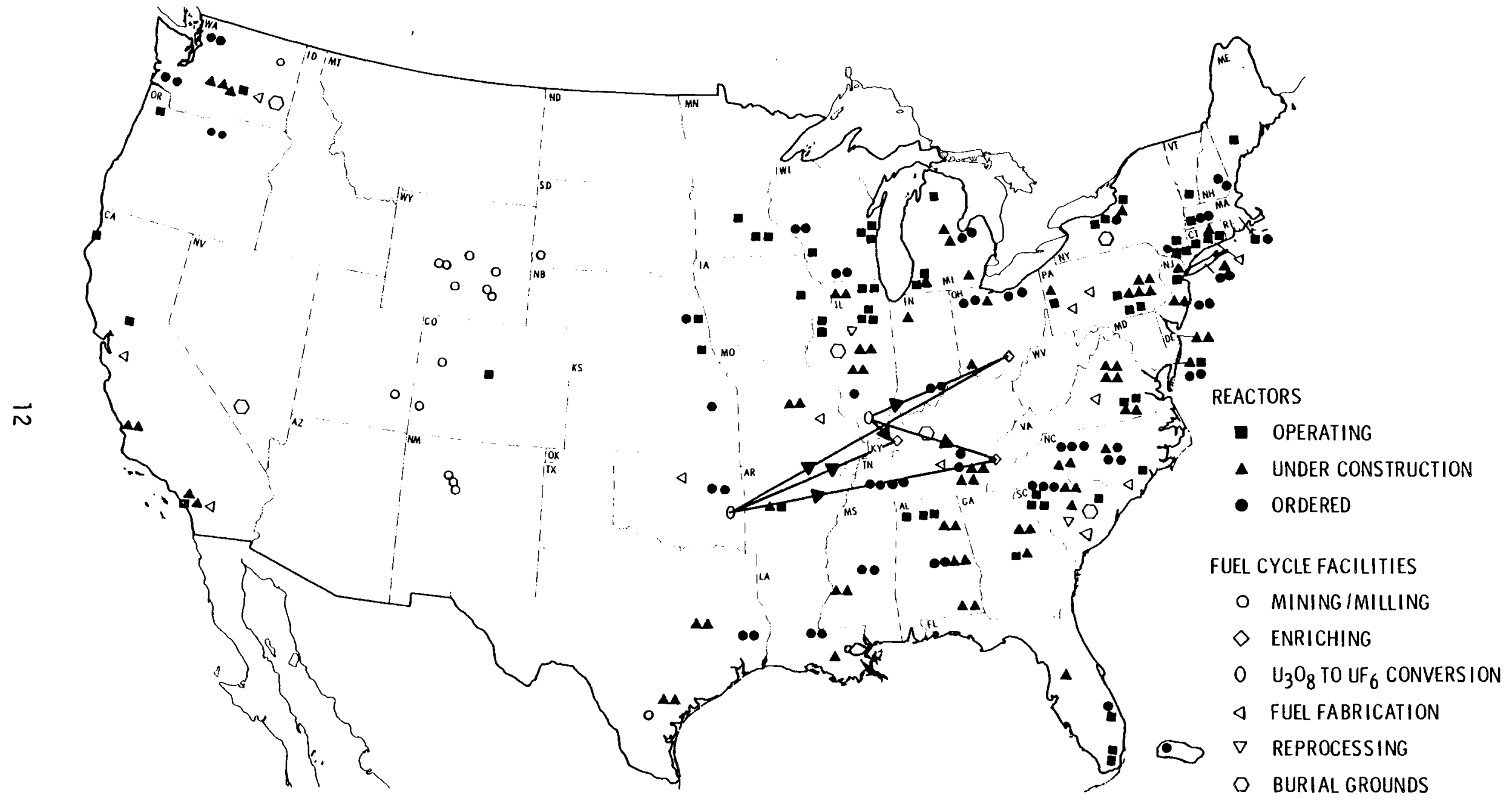

FIGURE 6. Domestic Shipping Pathways for Natural UF 6 


\subsubsection{Enriched $\mathrm{UF}_{6}$}

Enriched $\mathrm{UF}_{6}$ is shipped from the gaseous diffusion plant to a $\mathrm{UO}_{2}$ conversion facility. As indicated in Figure 1 , the $\mathrm{UO}_{2}$ conversion facility is generally located at the fuel fabrication facility. Enriched UF 6 , unlike natural $\mathrm{UF}_{6}$, is not exempt from classification as a fissile material. Therefore, it cannot be shipped as LSA material. Usualiy transported quantities constitute a Type $B$ quantity of radioactive material under NRC regulations. Type B packaging in the form of protective overpacks for 2.3-metric ton $\mathrm{UF}_{6}$ capacity and 9-metric ton UF 6 cylinders are used to satisfy the transportation accident test criteria of $10 \mathrm{CFR} 71$. Five 2.3-metric ton cylinders with overpack or one 9-metric ton cylinder with overpack can be shipped by truck. Sixteen 2.5-metric ton or four 9-metric ton cylinder can be shipped on a railroad flatcar. Truck shipment in 2.3-metric ton cylinders with overpacks is generally used for enriched $U_{6}$. A typical shipment is shown in Figure 7. Possible shipping pathways between the enrichment plants and the $\mathrm{UO}_{2}$ conversion facilities are shown in Figure 8.

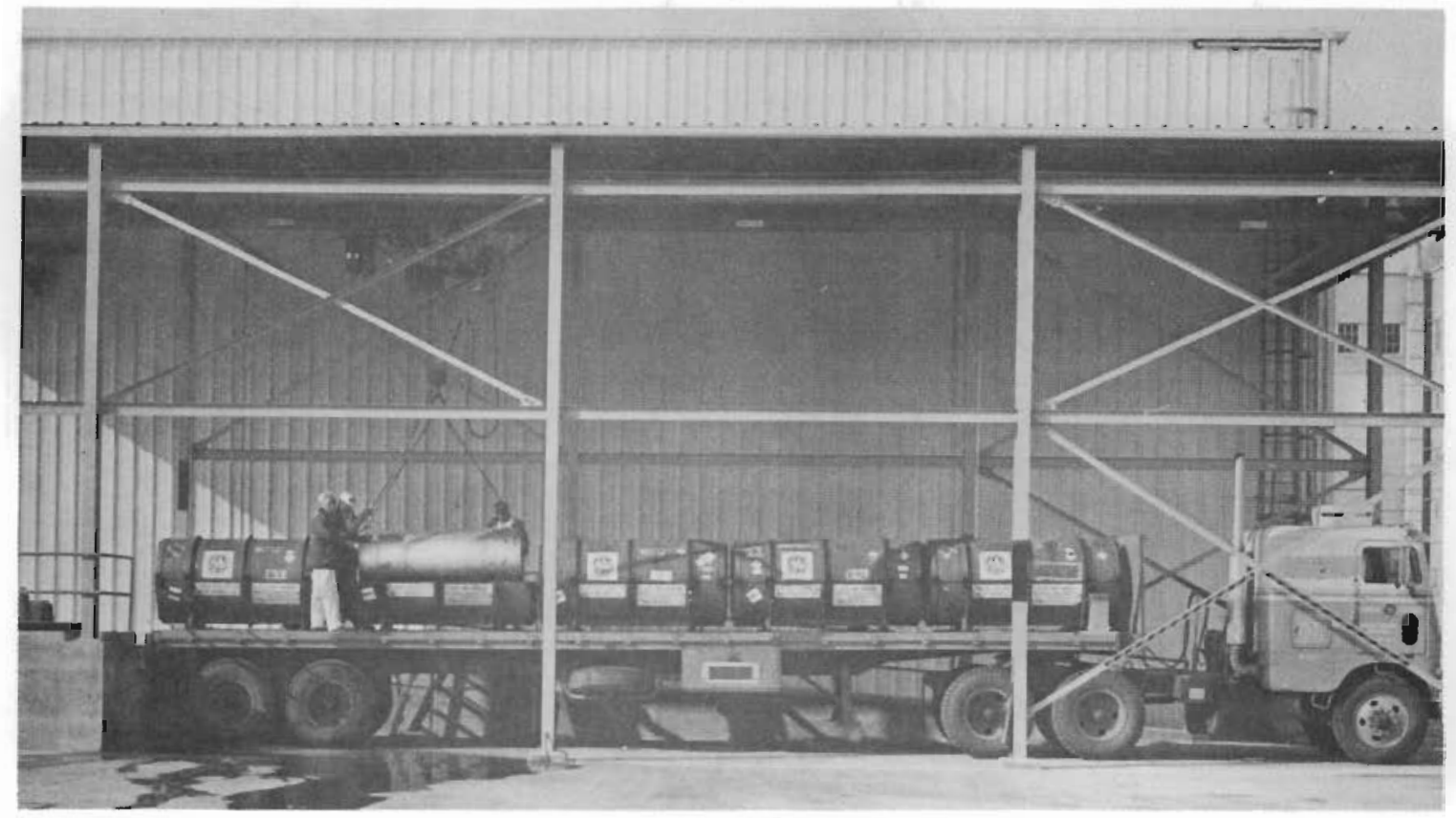

FIGURE 7. 2.3-Metric Ton UF 6 Cylinders with Overpack ${ }^{(1)}$ 


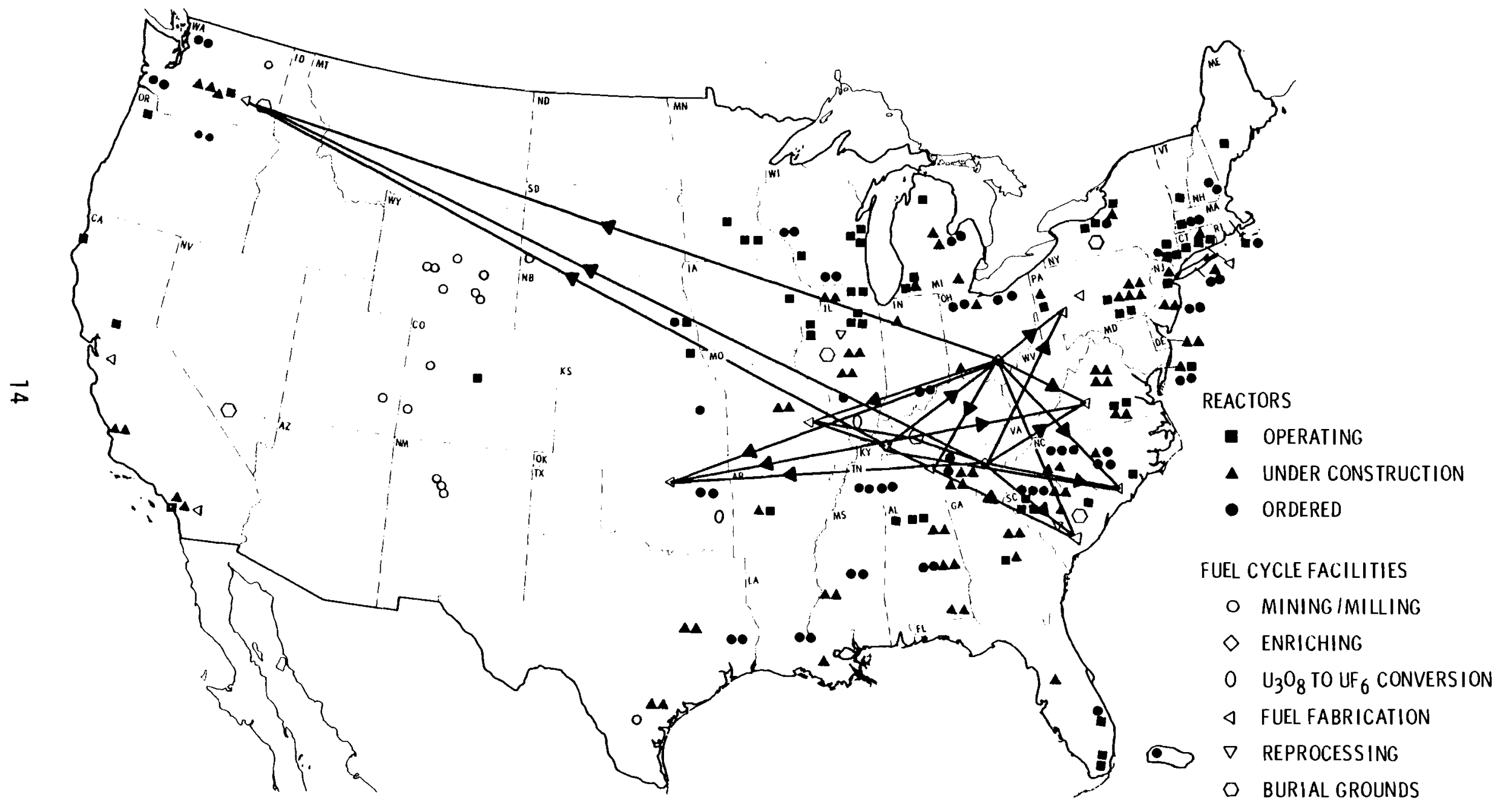

FIGURE 8. Possible Domestic Shipping Pathways for Enriched UF $_{6}$ 


\subsubsection{Depleted $\mathrm{UF}_{6}$}

As indicated in Figure 1 , depleted uranium $\left(0.2 \%-0.3 \%{ }^{235} U\right)$ may be shipped from the enrichment plant stockpiles to the fuel fabrication facilities for use in mixed oxide or fast breeder reactor fuels. It is transported in the same manner as natural $\mathrm{UF}_{6}$.

\section{$3.5 \mathrm{UO}_{2}$ TO MANUFACTURERS OF FUEL ELEMENTS}

There are currently three facilities in operation that produce $\mathrm{UO}_{2}$ and transport it to other facilities for the manufacture of fuel elements. These facilities are located at Erwin, Tennessee; Cimarron, Oklahoma; and Hematite, Missouri. Enriched $\mathrm{UO}_{2}$ can be shipped in DOT specification $6 \mathrm{~L}$ or $6 \mathrm{M}$ containers, or containers approved by NRC. Truck transport is generally used.

\subsection{FRESH FUEL ELEMENTS FROM FUEL FABRICATION PLANT TO REACTOR}

At the fuel fabrication plant, $\mathrm{UO}_{2}$ (or mixed $\mathrm{UO}_{2}$ and $\mathrm{PuO}_{2}$ ) pellets are placed in zircaloy (for LWRs) or stainless steel (for LMFBRs) tubes. These tubes are banded together to form fuel elements for nuclear reactors. These fresh fuel elements are transported to the reactor in protective outer packages designed to prevent damage to the fuel elements in transit. Typically, one PWR or two BWR fuel elements are placed in a protective overpack designed to protect the valuable fuel element from damage during transport. These overpacks are usually shipped to the reactor by truck. Six containers of PWR fuel or sixteen containers of BWR fuel are typically placed on a standard truck trailer. Normal tiedown techniques are used. A fresh fuel shipment is pictured in Figure 9. Shipments of mixed oxide fuel may require special transport equipment or procedures to guard against theft of the fuel.

\subsection{SPENT FUEL ELEMENTS FROM REACTOR TO REPROCESSING PLANT}

After irradiation in the reactor, nuclear fuel contains residual uranium (about $0.9 \%$ enrichment at anticipated exposures), plutonium and highly radioactive fission products. The radioactive decay processes 


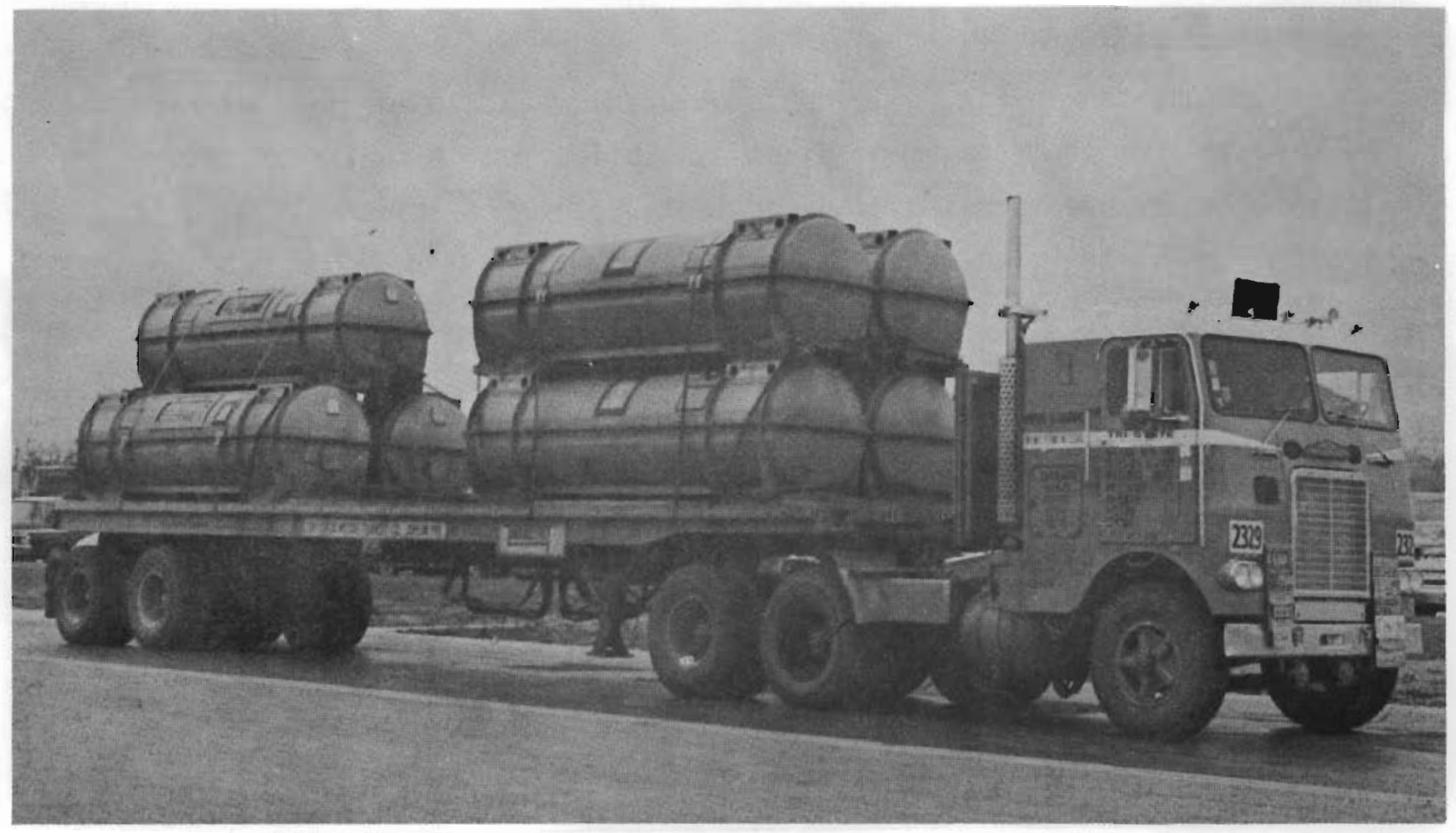

FIGURE 9. Fresh Fuel Shipment ${ }^{(2)}$

also generate large amounts of decay heat. The spent fuel elements are stored at the reactor a minimum of 120 days to allow radioactivity and heat generation levels to decrease before they are transported to the reprocessing plant.

Shipments of spent fuel have been made in the U.S. for many years. The physical properties of spent fuel (large gamma and neutron radiation doses, large heat generation rates, typical1y 3.6-m length of the elements) combine with the contraints of the transportation regulations to place stringent requirements on spent fuel shipping casks. Shielding from fission product gamma rays is provided by a thick (typically 10- to 20-cm) layer of lead or depleted uranium. Neutron shielding is provided by water or a hydrocarbon such as epoxy resin. Heat removal is accomplished either by natural convection cooling fins or by diesel-driven blowers. 
These factors make spent fuel casks large and very massive. Casks that can be shipped by truck without overweight permits (cask weight about 22-metric tons) are limited to 1 PWR or 2 BWR fuel elements. Overweight truck casks (cask weight about 36-metric tons) can handle up to 3 BWR or 7 BWR elements. Rail casks have been designed that can haul up to 12 PWR or 32 BWR assemblies. A picture of a legal weight truck cask is presented in Figure 10. This cask is cooled by natural convection. The IF 300 rail cask is shown in Figure 11 . The inner cavity of this cask is filled with water. Heat is transferred from the fuel to the outer surface of the cask by natural convection. The cask is ultimately cooled by two diesel-driven blowers.

Spent fuel casks must conform to handling requirements at the reactor fuel storage basin and at the fuel storage pool at the destination. Fuel is loaded and unloaded under water to provide radiation shielding to workers during these operations. The cask is in a horizontal configuration. The spent fuel cask must have lifting points for the cask handling cranes at these facilities and its weight cannot exceed the capacity of the cranes. Casks must also be designed to facilitate decontamination before the loaded cask is shipped to the reprocessing plant and before the empty cask is returned to the reactor. Special cradles and tie-downs are required on the transport vehicle to hold the massive cask in position during transportation. Usually a dedicated transport vehicle ${ }^{(a)}$ is provided with the cask.

The choice of transport mode for spent fuel is largely one of economics and convenience. Some reactors do not have rail sidings. Although intermodal shipments are possible from these sites, rail shipments are not expected to be made unless a rail siding is relatively close to the site. Rail shipments appear to have economic advantages, $(b)$ since larger casks

(a) A dedicated transport vehicle is used exclusively to transport radioactive fuel cycle materials.

(b) Proposed regulations of the American Association of Railroads would require that spent fuel be carried in "special trains" that carry no other freight and travel at speeds less than $35 \mathrm{mph}$. The additional charges made for this service may erase the economic advantages of rail shipment of spent fuel.(6) 


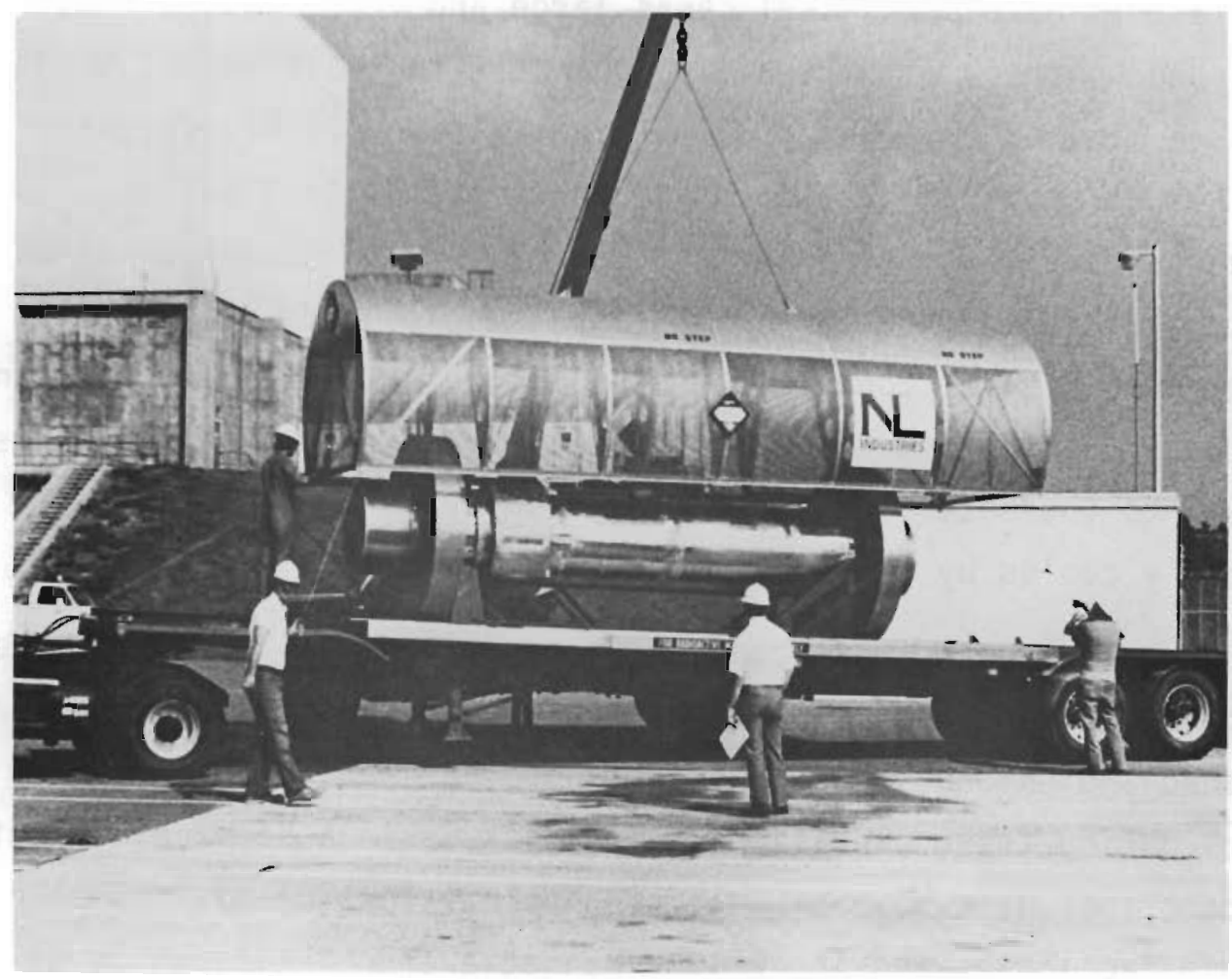

FIGURE 10. Spent Fuel Cask on Truck Trailer(3)

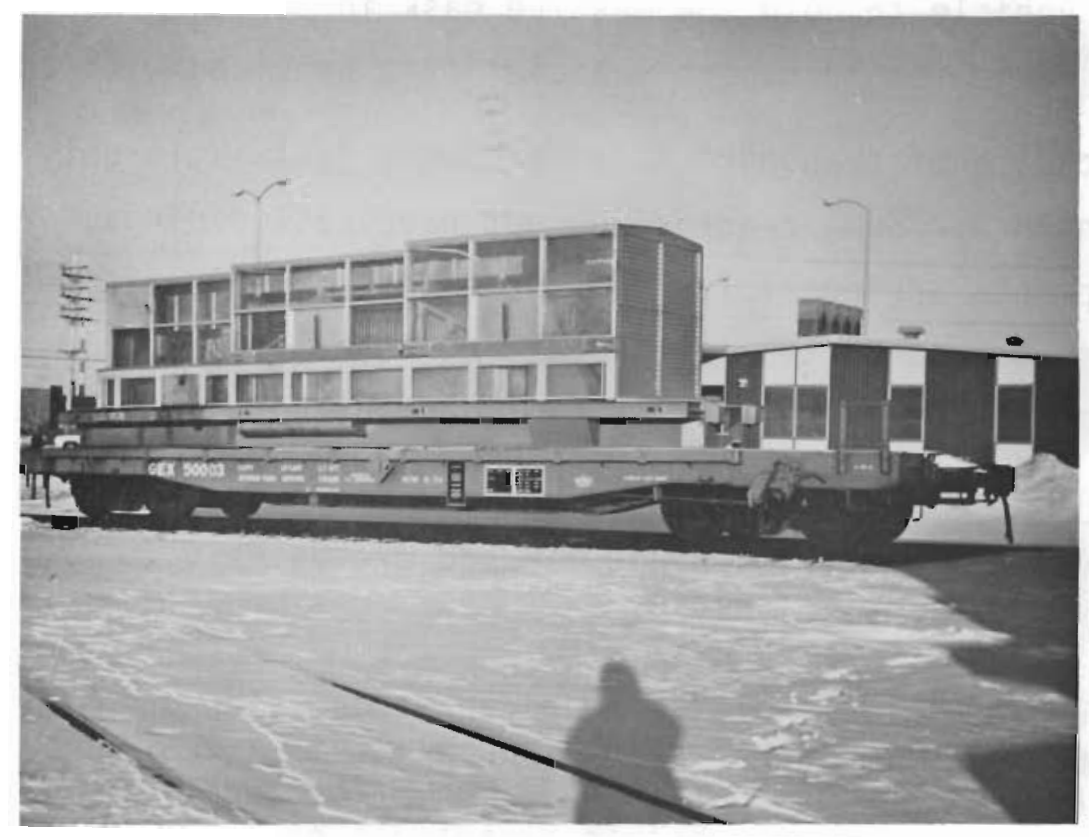

FIGURE 11. The IF 300 Spent Fuel Cask on Rail Car (3) 
provide better payload-to-weight ratios. Truck casks using overweight permits also appear attractive economically, al though shipment of overweight casks through several states can be difficult because of variations in the policies of the states regarding issuance of overweight permits.

\subsection{REPROCESSING}

Spent fuel is not currently being reprocessed. In the completed fuel cycle, the fuel bundles are chopped into short sections and the fuel material is acid-leached from the cladding at the reprocessing plant. The fission products are separated from the uranium and plutonium and stored as liquids in underground tanks for up to 5 years, at which time they will be solidified by an as yet undetermined process.

\subsubsection{Solidified High Level Waste}

High level waste will be solidified in stainless steel containers $30 \mathrm{~cm}$ (12 in.) to $60 \mathrm{~cm}$ (24 in.) in diameter and $3 \mathrm{~m}$ (10 ft) to $4.5 \mathrm{~m}(15 \mathrm{ft})$ in length. These containers will be stored on site for up to 5 years before being transported to a federal facility for storage and eventual disposal. Although solidified high level waste shipping casks have not been built, conceptual studies have identified important design parameters. Solidified high level waste has radiation and heat generation properties that are similar to spent fuel and the shipping casks for solidified high level waste are expected to be similar to the spent fuel casks presently in use. One proposed design for a high level waste shipping cask ${ }^{(4,5)}$ would be about $3 \mathrm{~m}$ (10 ft) in diameter and $4.6 \mathrm{~m}$ ( $15 \mathrm{ft}$ ) long and would accommodate 9 canisters of solidified high level waste. (Each waste canister is about $30 \mathrm{~cm}$ in diameter and $3 \mathrm{~m}$ long.) Gamma shielding is provided by $20 \mathrm{~cm}$ ( 8 in.) to $36 \mathrm{~cm}$ (12 in) of lead or depleted uranium and neutron shielding would be furnished by $10 \mathrm{~cm}$ (4 in.) of borated water. The cask would be cooled by natural convection cooling fins. The loaded cask would weigh about 90 metric tons and would be transported on a dedicated railroad flatcar. A conceptual drawing of a high level waste shipping cask on a railroad flatcar is presented in Figure 12. 


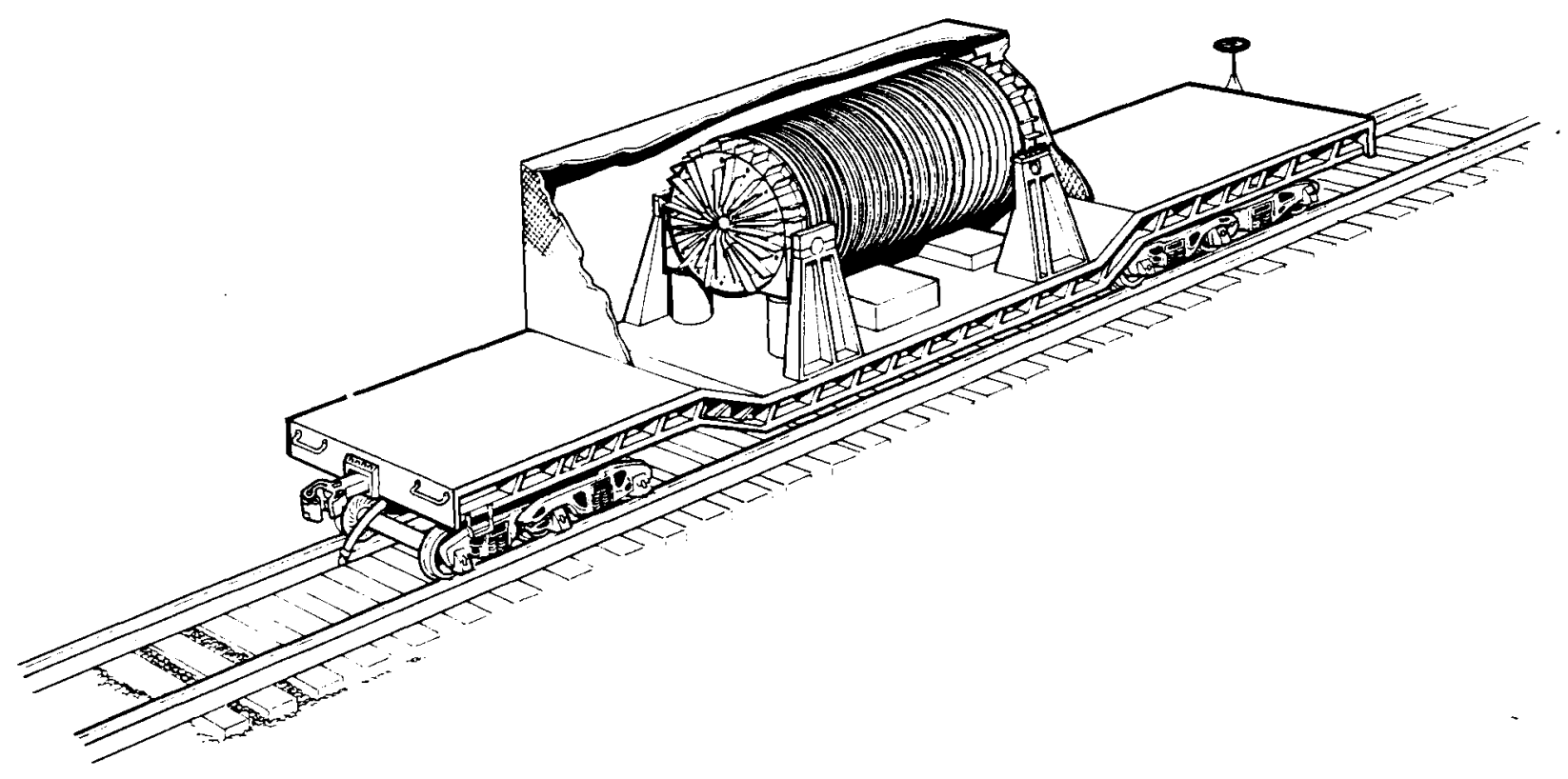

FIGURE 12. High Level Waste Shipping Cask and Railcar (7)

\subsubsection{Plutonium}

Plutonium will be separated from the spent fuel at the reprocessing plant and converted to $\mathrm{PuO}_{2}$ powder before it is shipped. Plutonium has been transported for many years for research and weapons programs. This plutonium is shipped in DOT specification 6M shipping containers or an approved equivalent. A typical 6M container consists of a 5-liter (15-gallon) steel drum with a 12.7-cm (5-in.) inner container of schedule 80 steel pipe closed at the bottom by a welded $1.2-\mathrm{cm}(1 / 2$ in.) steel plug. The containers are separated by Celotex ${ }^{(\mathbb{P})}$ insulating material. The plutonium is prepackaged in two metal cans each containing about $2.2 \mathrm{~kg}$ (5 1b) of plutonium dioxide. These cans are placed inside the inner container which is sealed with a gasketed pipe plug for transport. Most plutonium shipments in the U.S. are made by truck. One hundred twenty $6 M$ containers can be transported in a standard sized truck van. (If the number is not limited by criticality safety considerations or radiation dose limitations.) 
Federal Regulations (Title 10, Code of Federal Regulations, Part 73) require that shipments of over $2 \mathrm{~kg}$ of plutonium be protected in transit from diversion of the fissile material or sabotage. The regulations require that truck shipments follow procedures that have been approved by NRC. Containers must have tamper-indicating seals and no cargo transfers are permitted en route. Transport vehicles must be equipped with radio-telephones and the driver must make periodic reports to his dispatcher. Two persons must ride in the transport vehicle. If the transport vehicle is not equipped with special features to immobilize the trailer and provide physical deterrents to entry into the cargo compartment, the shipment must be accompanied by an escort vehicle with two armed guards. Systems currently under development include armored cabs and cargo compartments, special hinges and locking devices on cargo compartment doors, cargo compartment intrusion penalties (toxic gas or liquids, for example) and vehicle immobilization features (wheel or steering mechanism locks or engine or drive line disability mechanisms). These features can substantially increase tractor and trailer weights.

The contents of the 6M shipping container are limited to a maximum heat generation rate of 10 watts. Plutonium that is expected to be separated from discharged plutonium recycle fuel is expected to generate heat at a rate of about 20 watts $/ \mathrm{kg}$ and to produce a radiation dose requiring shielding because it contains greater percentages of the isotopes ${ }^{238} \mathrm{Pu}$ and ${ }^{241} \mathrm{Pu}$. A conceptual design has been developed for a container that can carry $32 \mathrm{~kg}$ of $\mathrm{Pu}$ from second generation $\mathrm{Pu}$ recycle fue1. (8) The package consists of an inner and outer container separated by about $28 \mathrm{~cm}$ (11 in.) of hydrogenous material providing thermal insulation, neutron shielding and some impact protection. Plutonium dioxide is prepackaged in four $15-\mathrm{cm}$ (6-in.) diameter by $30-\mathrm{cm}\left(12-\mathrm{in}_{\text {.) }}\right.$ high stainless steel canisters. The canisters are placed in an inner stainless steel pressure vessel $16 \mathrm{~cm}$ (6 1/2 in.) in diameter by $1.3 \mathrm{~m}$ (53 in.) high. The outer container is also a pressure vessel. It is approximately $7.5 \mathrm{~cm}$ (30 in.) in diameter and $1.8 \mathrm{~m}$ (72 in.) high. The loaded container weighs about $1360 \mathrm{~kg}(3000 \mathrm{lb})$. About 7 of these containers could be transported in a safeguards equipped truck without the use of overweight permits. 


\subsubsection{Slightly Enriched UF $_{6}$}

The uranium separated from the spent fuel at the reprocessing plant is slightly enriched (about $0.9 \%$ ) ${ }^{(9)}$ in $235 U$. It is expected that the uranium will be converted to UF 6 at the reprocessing plant before it is shipped. Most of this $\mathrm{UF}_{6}$ is expected to be transported to the enrichment plant to be used as feed stock. As indicated in Figure 1, some of this material may be sent to the mixed oxide fuel fabrication plant for use in plutonium recycle or LMFBR fuels. Uranium of less than $1 \%$ enrichment is exempt from classification as a fissile material and can be shipped as LSA material. The slightly enriched $U_{6}$ from the fuel reprocessing plant can therefore be transported in the same 9-metric ton (10-ton) and 12.7-metric ton (14-ton) cylinders used to ship natural $U_{6}$.

\subsection{TRANSPORTATION OF RADIOACTIVE WASTES FROM FUEL CYCLE FACILITIES}

Radioactive wastes are generated at all fuel cycle facilities. These wastes include an assortment of materials with a wide range of contamination levels. The waste includes such items as cladding hulls and radioactive gases from reprocessing plants, resins and filter cartridges from liquid cleanup systems at reactors and fuel storage pools in reprocessing plants, HEPA filters and a wide variety of radioactive trash from all facilities including contaminated failed or obsolete equipment, plastic bags, gloves, protective clothing and other articles of wood, paper, plastic and rubber. Some of the waste is contaminated with transuranic (TRU) elements and under currently proposed regulations $(10)$ will require transportation to a federal repository for such wastes. Under current regulations, non-transuranic (Non-TRU) wastes can be disposed of at a commercial burial ground. In general, wastes from reactors, mills, $\mathrm{UF}_{6}$ conversion and uranium enrichment plants are Non-TRU. Waste from mixed oxide fuel fabrication facilities is almost entirely TRU contaminated. Approximately $70 \%$ (by volume) of reprocessing plant wastes are contaminated with TRU elements (as we 11 as other radioactive contaminants). (11) 
A variety of treatment processes are available or under development to stabilize the contamination on the waste and/or to reduce waste volumes. Contaminated liquids, for example, may be fixed in a solid such as bitumen, urea-formaldehyde or cement. This will increase waste volumes, but stabilize the contamination for burial. The volume of solid radioactive trash can be reduced in many ways including mechanical compaction, burning, pyrolysis or chemical digestion. These processes generally decrease the volume of the material to be shipped and in many cases the weight as well. Transportation and waste disposal costs are thereby reduced.

An assortment of shipping containers will be used for radioactive wastes. Container requirements depend on the physical form of the waste, the waste treatment process used, the radiation levels of the waste and the shipping destination. An outline of the containers and transportation modes in use or anticipated to be used for various waste forms is presented below.

\subsubsection{Cladding Hulls}

Cladding hulls consist of the chopped sections of Zircaloy tubing with some residual fuel and stainless steel inconel fuel element hardware removed from the head end process at the reprocessing plant after the acid-leach operations are completed. The hulls are highly radioactive and are contaminated with transuranic elements. A variety of treatments have been proposed for cladding hulls. Shipping container requirements are highly dependent on the treatment selected. The treatments include mechanical compaction or melting to reduce waste volumes and interim storage at the reprocessing plant for periods of up to ten years to allow the radioactivity levels to decrease. Cladding hulls are not currently a transportation requirement in the U.S. Conceptual designs have been developed for shipping containers to transport the hulls from the reprocessing plant to a federal repository for transuranic waste. In one proposed design, ${ }^{(12)}$ the hulls would be compacted and placed in stainless steel cans about $23 \mathrm{~cm}$ ( 9 in.) in diameter by $3 \mathrm{~m}$ (10 ft) long. Twenty-seven of these cans would be carried in a cask $1.8 \mathrm{~m}(6 \mathrm{ft})$ in diameter by $3.6 \mathrm{~m}(12 \mathrm{ft})$ long, weighing 80 metric 
tons $(180,000 \mathrm{lb})$. The cask has about $14 \mathrm{~cm}(51 / 2$ in.) of lead gamma shielding and an unspecified amount of hydrogenous neutron shielding. It is cooled by natural convection cooling fins. The cask carries the hulls from about 45 metric tons of LWR fuel cooled 1 year after reactor discharge. A cask design proposed by Allied General Nuclear Services (12) would transport untreated hulls in stainless steel cylinders $1.1 \mathrm{~m}$ (42 in.) in diameter by $2.4 \mathrm{~m}(8 \mathrm{ft})$ long. A filled cylinder is shipped in a finned cylindrical cask with a $2.5 \mathrm{~cm}(1 \mathrm{in.})$ steel inner wall, $17 \mathrm{~cm}$ (6.5 in.) of lead shielding and a $5 \mathrm{~cm}$ (2 in.) thick outer steel shell. Because of the cask weights, both must be transported by rail.

3.9.2 Radioactive ${ }^{85} \mathrm{Kr}$ Gas

The radioactive noble gas ${ }^{85} \mathrm{Kr}$ is a byproduct of spent fuel reprocessing. Although current regulations permit release of ${ }^{85} \mathrm{Kr}$ to the atmosphere, future developments may require its collection and transportation to a federal repository. (13) It has been proposed that this gas be collected in 50-1iter gas cylinders $23 \mathrm{~cm}$ (9 in.) in diameter by $1.3 \mathrm{~m}$ (52 in.) high at a pressure of 150 atmospheres and shipped to a federal repository for storage. Three of these cylinders would be shipped in a cask weighing about 6.3 metric tons $(14,000 \mathrm{lb})$. The cask is filled with water that acts as shielding and a heat transfer media. It is cooled by natural convection. Six of these casks could be carried on a standard railroad flatcar. (14)

\subsubsection{Radioactive Iodine}

Radioactive iodine will be removed from spent fuel at the reprocessing plant and fixed as a solid, possibly as potassium iodide. The amount of waste generated annually is sma11. Only one 450-kg (1000-1b) shipment/yr is anticipated from each $1500 \mathrm{MTHM} / \mathrm{yr}$ reprocessing plant. The shipping container will probably be a 210-1iter (55-gallon) drum with an overpack.

\subsubsection{Radioactive Tritium Gas}

Radioactive tritium gas may also be collected at the reprocessing plant and fixed as a solid (possibly $\mathrm{Ca}(\mathrm{OT})_{2}$ ). Several available shipping containers could be used, including the DOT specifications 6M container. 
The tritiated calcium hydroxide could also be put in drums and transported in Type B overpacks such as the NECO B2 ${ }^{(15)}$ or the Protective Packaging, Inc. Super Tiger. (16) The Super Tiger can accommodate forty-two 210-1iter drums and has a maximum payload weight of 2.2 metric tons $(5000 \mathrm{lb})$.

The outside dimensions of the overpack are $1.3 \mathrm{~m} \times 2.3 \mathrm{~m} \times 3.5 \mathrm{~m}$ (54 in. $x 91$ in. $x 142$ in.).

\subsubsection{Low Level Waste}

Low level wastes are produced at all fuel cycle facilities. They include a wide variety of materials that generally do not require shielding during transportation. Combustible low level wastes will probably be compacted before they are transported. Much low level waste meets the requirement of Low Specific Activity (LSA) material, requiring strong tight industrial packaging when shipped in exclusive-use vehicles. Two hundred ten liter drums have been widely used for such shipments. Type A quantities of low level waste must be shipped in containers meeting the requirements of DOT specification $7 \mathrm{~A}$ packaging. A variety of DOT specification metal drums, plywood boxes, fiberboard boxes and fiberboard drums have been determined to meet the Spec $7 \mathrm{~A}$ requirements. ${ }^{(17)}$ The most common shipping containers for these wastes are 210-1iter (55-galion) drums. Wastes that are not contaminated with transuranic elements will be shipped to a commercial burial ground. The wastes that are contaminated with TRU elements will be shipped to a federal repository. The shipping containers used for these wastes must also meet as yet unspecified repository requirements as we 11 as satisfy DOT transportation regulations. Low level wastes can be shipped by truck or railcar. Typical truck shipments contain sixty-four 210-1iter (55-gal1on) drums in a $10 \mathrm{~m}$ (33 ft) enclosed trailer. The ATMX-600 series railcar $(18)$ in use at ERDA's Rocky Flats facility has been very effective in transporting large quantities of low-level TRU waste. These cars are specially reinforced to satisfy the requirement of a Type $B$ package. The interior dimensions of the car are $2.7 \mathrm{~m} \times 2.7 \mathrm{~m} \times 15.2 \mathrm{~m}(9 \mathrm{ft} \times 9 \mathrm{ft} \times 50 \mathrm{ft}$ ) and it has a useful load of 45.8 metric tons $(101,000 \mathrm{lb})$. The car can carry two hundred sixteen 2101 iter drums or two $2.4 \mathrm{~m} \times 2.4 \mathrm{~m} \times 6.1 \mathrm{~m}(8 \mathrm{ft} \times 8 \mathrm{ft} \times 20 \mathrm{ft})$ cargo containers each containing 70 drums or plywood boxes of various sizes. The Type $B$ overpacks described in the previous section can also be used for Type $B$ quantities of low level waste. 


\subsubsection{Intermediate Level Waste}

Intermediate level wastes require shielding during transportation. Typical intermediate level wastes are coolant cleanup system resins and evaporator bottoms from reactors and HEPA filters and contaminated failed or obsolete equipment from reprocessing plants. Liquid wastes are generally immobilized by mixing them with concrete, bitumen or urea-formaldehyde before they are transported for disposal. Some of the reprocessing plant wastes will be contaminated with TRU elements and will be transported to a federal repository. The reactor wastes and the remainder of the reprocessing plant wastes will be shipped to a commercial burial ground.

Intermediate level wastes, just as low level wastes, can be either LSA, Type A, Type B, or large quantities of radioactive material. In the past, much of the dry intermediate level waste and immobilized liquids have been packaged in 210-1iter drums and transported in shielded overpacks or shielded truck vans. The inexpensive drums are disposed of with the waste and the more expensive overpacks are reused. Shielded containers meeting the requirements of DOT Specification $7 A$ are required for Type $A$ quantities of intermediate level waste. Shielded containers meeting the Spec $7 \mathrm{~A}$ requirements are available in various sizes with a variety of thicknesses. In recent years, shipments of reactor wastes, which are mostly Type A or LSA quantities of radioactive material have been made in large, 1.4 to $5.6 \mathrm{~m}^{3}$ (50-200 $\left.\mathrm{ft}^{3}\right)$, cylindrical steel drums placed in shielded shipping casks. Indications are that the current trend is toward more extensive use of these larger waste containers. It is felt that these containers reduce personnel exposure in packaging and handling the waste, and make more efficient use of the shielded overpack. (19) A waste shipping cask on a truck trailer is shown in Figure 13.

Type $B$ overpacks are required for Type $B$ and large quantities of radioactive material. Available overpacks range in size from containers for one 210-1iter (55-gal1on) drum to large casks requiring overweight permits. A variety of shielding thicknesses are available and the shielding thickness can be varied in some containers by means of removable lead inserts. 


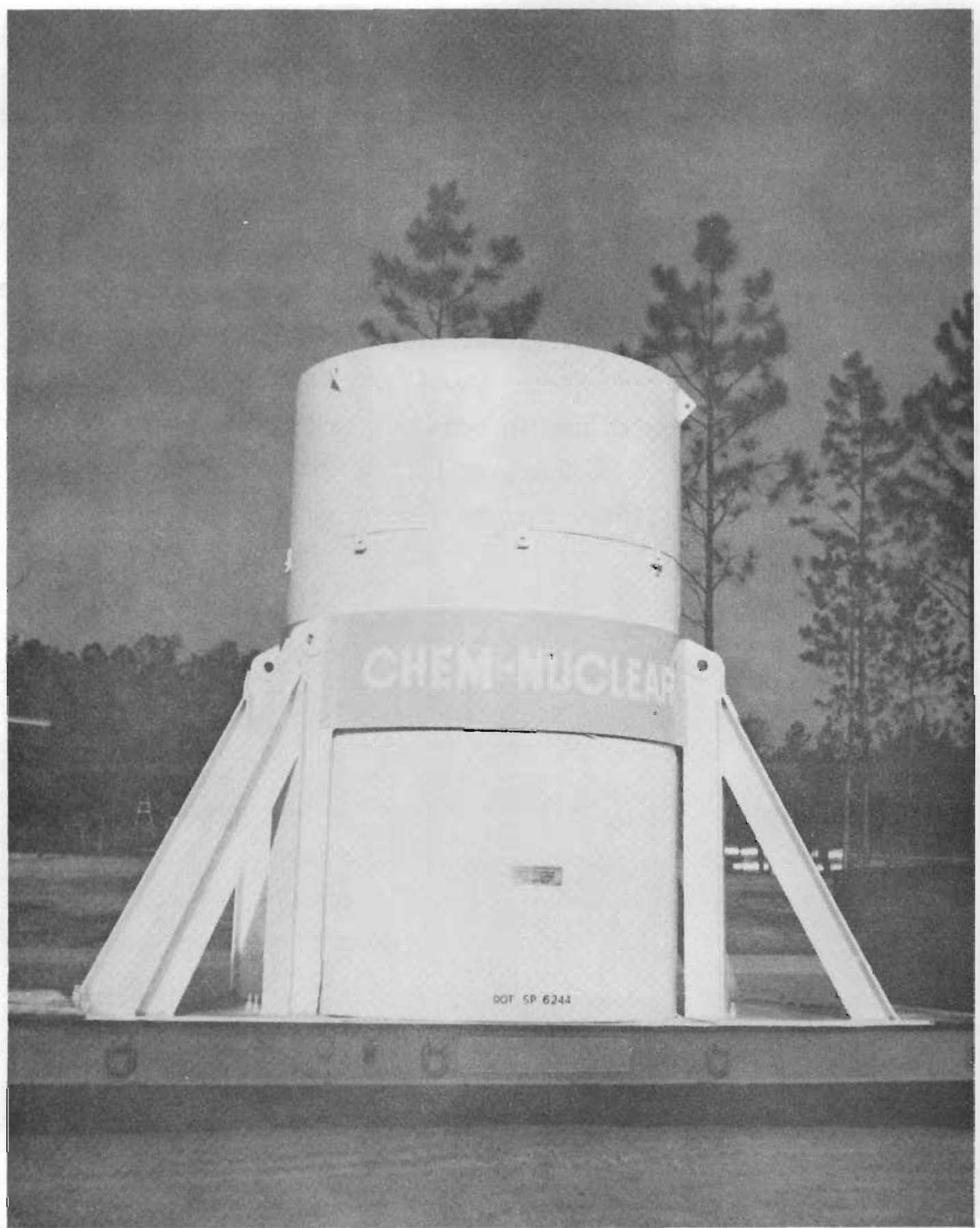

FIGURE 13. Radioactive Waste Shipping Cask on Truck Trailer (20) 


\subsection{IMPORT/EXPORT ACTIVITIES}

The previous discussion has dealt with domestic shipments of fuel cycle materials. There are also some import and export shipments of these materials. These shipments occur primarily in the front end of the fue 1 cycle and are usually associated with ERDA sales of enriching services to foreign customers. $U_{3} \mathrm{O}_{8}$ and natura $\mathrm{UF}_{6}$ are imported and enriched $\mathrm{UF}_{6}$ and $\mathrm{UO}_{2}$ powder and pellets are exported. For the most part, the containers previously described are used for these materials. They are carried almost exclusively on cargo vessels, so the container must be approved for water-borne transport. Usual1y, to meet the requirements of the transportation regulations in both the shipping and receiving country, the container must be approved by the International Atomic Energy Agency. Most containers that have been approved by DOT and NRC meet the IAEA requirements. 


\subsection{TRANSPORTATION SERVICES}

The trend in transportation of radioactive materials is for fue 1 cycle facilities to hire a specialized company to arrange transportation services for their radioactive material. This trend is due to a variety of factors. Transportation regulations are complicated. Expert interpretation of the regulations is often required. Shipping requirements at an individual site are usually not sufficient to warrant full time employment of a transportation expert. Specialized equipment is necessary for packaging and transporting radioactive material. It is not economically attractive for an individual facility to own a shipping container unless it can use the container continuously. The nuclear industry presently supports one dedicated fleet of trucks and specially trained drivers (Tri-State). As nuclear transportation requirements grow, it is expected that other common carriers will also develop special capabilities for transporting radioactive materials.

Some fuel cycle facilities own or lease shipping containers (many times with specialized truck trailers) and deal directly with common carriers, contract carriers, or specialized haulers to transport their material. This is the typical case in the front end of the fuel cycle (mining, milling and fuel preparation activities) where materials of relatively low hazard potential are shipped and shipping container requirements and regulations are relatively straightforward.

Companies specializing in spent fuel shipments typically design, obtain licenses for, build and lease spent fuel shipping casks. The casks are usually furnished with a specially designed transport vehicle. Companies engaged in the transportation of spent fuel include General Electric, Nuclear Fuel Services, Transnuclear, National Lead and Nuclear Assurance Corporation.

Waste shipments are usually handled by a company specializing in waste disposal operations. These companies contract with the fuel cycle facility to furnish the proper shipping container for the waste, make appropriate arrangements with disposal site and transport the waste. The three 
major companies in the U.S. providing this service are Chem-Nuclear Systems with headquarters in Bellevue, Washington; Nuclear Engineering Company (NECO) in Louisville, Kentucky; and Hittman Nuclear and Development Corporation of Columbia, Maryland. Chem-Nuclear and NECO also operate low level waste burial grounds. Chem-Nuclear's facility is located in Barnwe11, South Carolina. NECO operates facilities at Beatty, Nevada; Richland, Washington; Moorehead, Kentucky and Sheffield, Illinois.

Although many trucking companies act as common carriers of radioactive materials, there are three companies that as a group haul a large percentage of the fuel cycle shipments in the U.S. The largest company in this field is Tri-State Motor Transit with headquarters in Joplin, Missouri. By their own estimates, Tri-State hauls about $70 \%$ of the radioactive materials shipped annually in the U.S. They have a dedicated fleet of trucks and drivers for radioactive material. They also own some specialized equipment such as trailers with cradles for $U_{6}$ cylinders or spent fuel casks permanently attached and armored tractors for safeguards shipments. They can also furnish armed drivers and armed escorts for safeguards shipments. Their drivers receive special training for hauling radioactive materials. Other companies engaged in the truck transport of radioactive materials include Davis Transport, Moss Trucking and Home Transport. Several other companies do a relatively large business in localized areas.

There are other companies in the U.S. providing a variety of transporation services. ATCOR, Inc. of Peekski1l, New York, among others, provides shipping casks for rent. Many companies provide design and manufacturing services for shipping casks and there are a number of companies that supply radioactive material packaging.

In the past, most U.S. railroads have acted as common carriers of radioactive materials and shipped them, using the same procedures followed for routine shipments of other (non-radioactive) hazardous materials. Recently, however, the railroad industry has changed the way they propose to handle radioactive materials. Many eastern and southern railroads have refused to act as common carriers of radioactive materials. They will continue to handle these materials only on a 
contract basis. The American Association of Railroads has proposed amendments to Uniform Freight Classification 12 that would require that all shipments of spent fuel, radioactive waste, and empty shipping containers be carried only in special train service. They have also proposed a set of operating practices that would prohibit carriage of non-radioactive materials in the same train with radioactive materials, require a maximum speed of $35 \mathrm{mph}$ for special trains carrying radioactive materials, and require that one train be standing when a radioactive material special train meets, passes or is passed by another train. These operating practices would substantially increase the cost of shipping radioactive materials by rail. The final fate of these proposals is not known. They are currently being discussed in hearings before the Interstate commerce Commission.

Most of the import/export shipments of radioactive material in the U.S. are handled under contract to shipping companies such as Edlow International, Inc., Transnuclear, Inc. or Mitsubishi International. Most customers purchasing services from these companies are foreign companies buying enrichment services from ERDA. The service company typically obtains necessary permits and licenses and arranges for transportation of the material to and from the U.S. (usually in cargo vessels) and transportation within the U.S. The customer usually owns and furnishes the shipping container. Some large companies such as General Electric and Westinghouse provide their own transportation services. 


\subsection{PROJECTIONS OF TRANSPORTATION REQUIREMENTS}

This section gives a projection of the number of shipments, shipping distances and transportation requirements through the Year 2000.

Table 1 illustrates the current and projected transportation requirements of the nuclear power industry, the approximate number of shipments for each step in the fuel cycle in 1976 and projections for materials shipped in 1990 and 2000. The material flows are based on recent projections prepared for the Energy Research and Development Administration (ERDA). (21) A midgrowth case has been used. This case is based on the installed nuclear generating capacity presented in Table 2.

The projection assumes that reprocessing begins in 1981, recycle of plutonium in light water reactors begins on a limited basis in 1982 and that the fast breeder reactor is commercialized in 1995. An average plant capacity factor of $70 \%$ has been assumed.

The estimated number of shipments presented in Table 1 for each type of material transported in the fuel cycle are based on the reference shipping containers and transport modes listed in the table. The shipping containers and modes selected are believed to be typical of current practice or representative of methods that will be used in the future. Changes in the reference shipping system can significantly affect the number of shipments. Total shipping distances, using assumed average shipping distances, are also included. Shipping distances include return of empty containers and special equipment. Details concerning the table entries are given in the footnotes following the table. 
TABLE 1. Summary of Information on Projected Shipments of Radioactive Fue 1 Cycle Materials in the U.S.

\begin{tabular}{|c|c|c|c|c|c|c|c|c|c|c|c|c|c|c|c|c|c|c|}
\hline | fevel cycie step & $\begin{array}{l}\text { Material Shipped } \\
\text {. }\end{array}$ & Physical/chemical Form & Iypical shipping conta iner & quantity/container & Iransport Mode & Quantity/shi iment & 1916 Qu & 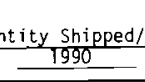 & $\frac{\gamma r}{20000}$ & 1976 & $\begin{array}{l}\text { isentsts } \\
1990 \\
1990\end{array}$ & $T^{20} 2000$ & Destinatior & 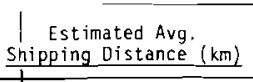 & 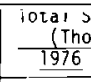 & 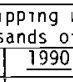 & 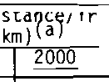 & 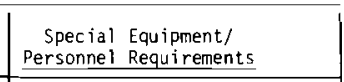 \\
\hline Milling & $\mathrm{U}_{3} \mathrm{O}_{8}$ & \begin{tabular}{|l} 
Fine Yellow Powder \\
\end{tabular} & \begin{tabular}{|l|l|} 
Steel Drums \\
\end{tabular} & $360 \mathrm{~kg}$ & Rai & 110 Oruns & $13,000 \mathrm{MT}$ (b) & $52,000 \mathrm{mT}$ & \begin{tabular}{|l|l|}
$82,000 M T$ \\
\end{tabular} & 350 & 1300 & 2100 & $\mathrm{UF}_{6}$ Conversion & 2500 & 880 & 3300 & 5200 & \begin{tabular}{|l|l} 
None \\
\end{tabular} \\
\hline \multirow[t]{2}{*}{$u_{6}$ Conversion } & Natural UF & \begin{tabular}{|l|l|} 
Volatilie Sol id \\
\end{tabular} & \begin{tabular}{|l|}
$10-$ Ton Cyl inder \\
\end{tabular} & 9 9MT & Truck & 2 cylinders & $13,000 \mathrm{~mm}$ (c) & $55,00004 \mathrm{~T}$ & \begin{tabular}{|l|l|}
$87,000 \mathrm{MT}$ \\
\end{tabular} & 700 & 3100 & 4800 & Enrichnent Plant & 800 & 1100 & 5000 & 7700 & 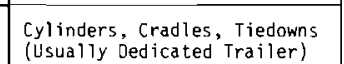 \\
\hline & Haste & Various Contaminated Sol ids & \begin{tabular}{|l|} 
Steel Orums \\
\end{tabular} & $210 ?$ & Truck & 64 Druns & $3,000 \mathrm{~m}^{\mathrm{s}(\mathrm{d})}$ & $10,00 \mathrm{~m}^{3}$ & $15,000 \mathrm{~m}^{3}$ & 220 & 750 & 1100 & Burial Ground & 800 & 180 & 600 & 880 & \\
\hline \multirow[t]{3}{*}{ Enricment } & Enriched $U_{6}$ & \begin{tabular}{|l|l|} 
volatile Sol id \\
\end{tabular} & 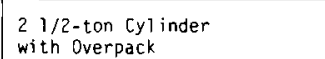 & $2.3 \mathrm{TT}$ & Truck & 5 cylinders & 2,300m & 10,000ms & $16,000 \mathrm{MT}$ & 200 & 900 & 1400 & Fuel Fabrication plan & 800 & 320 & 1400 & 2200 & 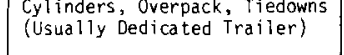 \\
\hline & Depleted $\mathrm{UF}_{6}(\mathrm{e})$ & \begin{tabular}{|l|l|} 
Volatilie solid \\
\end{tabular} & \begin{tabular}{|l} 
10-Ton Cylinder \\
\end{tabular} & 9MT & Truck & 2 cylinders & 0 & 1,400लт & $2,100 \mathrm{MT}$ & 0 & 80 & 120 & Fuel Fabrication Plant & 800 & 0 & 130 & 190 & 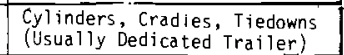 \\
\hline & Haste ${ }^{\circ}$ & 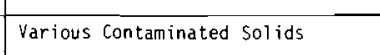 & Steel Druns & 2102 & & 64 Druns & $2,000 \mathrm{~m}^{3(\mathrm{~d})}$ & $5,70 \mathrm{~cm}^{3}$ & $11,000 \mathrm{~m}^{3}$ & 150 & 420 & 850 & Burial Ground & 800 & 120 & 330 & 680 & \begin{tabular}{|l|l|l|} 
None \\
\end{tabular} \\
\hline \multirow{4}{*}{ Fuel fabrication } & $\mathrm{UO}_{2}$ Fresh Fuel & Wo, Pellets in zircaloy tubes & Protective Overpack & 1 PWR or 2 BuR Flements & Truck & $\begin{array}{l}6 \text { PhR or } 16 \text { BWR } \\
\text { Containers }\end{array}$ & $1,500 \mathrm{mT} \mathrm{f}^{(f)}$ & $7,000 \mathrm{mT}$ & 11, 000MT & 270 & 1200 & 2000 & Reactor & 1000 & 540 & 2500 & 4000 & \begin{tabular}{|l|l|l|l} 
overpacks \\
\end{tabular} \\
\hline & $\begin{array}{l}\text { waste } \\
\text { hast }\end{array}$ & 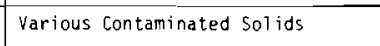 & Steel Druns & $210:$ & Truck & 64 Drums & $1,200 m^{3(d)}$ & $5,70 \mathrm{~m}^{3}$ & $9,000 \mathrm{~m}^{3}$ & 90 & 420 & 670 & Burial Ground & 800 & 70 & 340 & 540 & None \\
\hline & $P_{20}-\mathrm{UO}_{2}$ Fresh fue 1 & $P \mathrm{PuO}_{2}-\mathrm{UO}_{2}$ Pell lets in Zircaloy Tubes & \begin{tabular}{|l|} 
Protective overpack \\
\end{tabular} & I PuR or 2 EuR Elements & Truck & 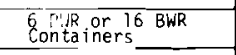 & 0 & 1,000MT & \begin{tabular}{|l|l}
$1,500 \mathrm{MT}$ \\
\end{tabular} & 0 & 180 & 260 & Reactor & 1000 & 0 & 360 & 520 & \begin{tabular}{|l} 
overpacks, Security Personne. \\
\end{tabular} \\
\hline & Wastes & \begin{tabular}{|l|l|l|l|l} 
Various TRU-Contaminated Solids \\
\end{tabular} & Steel Drums & $210:$ & Truck & 64 Drums & 0 & $2,300 \mathrm{~m}^{3}(\mathrm{~g})$ & $3,500 \mathrm{~m}^{3}$ & 0 & 170 & 260 & Federal Repository & 2500 & 0 & 430 & 650 & None \\
\hline \multirow[t]{3}{*}{ Power Production } & Spent fuel & 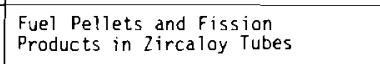 & Shielded cask & 2 FWR or 4 gur Elements & Truck & 1 cask & 500T & $1,200 \mathrm{r}^{(T)}$ & $2,20004 T$ & 110 & 1300 & 2400 & Reprocessing Plant & 1600 & 350 & 4200 & 7700 & 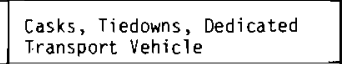 \\
\hline & Spent fuel & $\begin{array}{l}\text { Fuel Pellets and Fiss ion } \\
\text { Products in zircaloy }\end{array}$ & Shiel Jed Cask & 10 PWR or 24 BuR Element & Rail & 1 Cask & 1000\% & 4,800MT & 8,8004T & 30 & 1100 & 2000 & Reprocessing Plant & 1600 & 100 & 3500 & 6400 & $\begin{array}{l}\text { Casks, Tiedouns, Dedicated } \\
\text { Transport Vehicle }\end{array}$ \\
\hline & 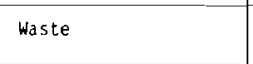 & \begin{tabular}{|l} 
Various contaminated Sol ids \\
\end{tabular} & 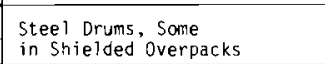 & 210. & Truck & 64 Druns & $\mid 2,000 \mathrm{~m}^{3(i)}$ & $60,000^{(i)}$ & $120,00 \mathrm{~m}^{3}(1)$ & 900 & 4500 & 9000 & Burial Ground & 800 & 720 & 3600 & 2200 & $\begin{array}{l}\text { Shiel ded Doverpacks ISome } \\
\text { shinents) }\end{array}$ \\
\hline \multirow[t]{8}{*}{ Reprocessing } & Plutonium & PuQ, Powder & Shiel ded container & $32 \mathrm{~kg}$ & Truck & 7 containers & 0 & ${ }_{40 M r}(j)$ & $1000 \mathrm{r}$ & 0 & 160 & 450 & Fuel Fabrication Plant & 1200 & 0 & 380 & 1100 & 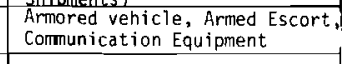 \\
\hline & $\begin{array}{l}\text { Sol idified High } \\
\text { Level Kaste }\end{array}$ & \begin{tabular}{|l} 
Boro-silicate Giass in \\
stainness steel Canisters
\end{tabular} & Shie lded Cask & $2 \mathrm{~m}^{3}$ & Rail & 1 Cask & ${ }^{\circ}$ & ${ }^{130 m^{3}(k)}$ & $600 m^{3(k)}$ & 0 & 70 & 300 & Federal Repository & 2500 & 0 & 350 & 1500 & $\begin{array}{l}\text { Cask, Tiedoms, Dedicated } \\
\text { Flatcar }\end{array}$ \\
\hline & cladding waste & $\begin{array}{l}\text { 2ircator Tubing, stainless } \\
\text { steel and Inconel Fittings }\end{array}$ & 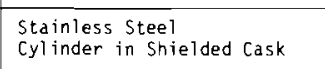 & $4.2 \mathrm{~m}^{3}$ & Rail & i cask & 0 & $1,600 m^{3}$ & $3,50 \mathrm{~m}^{3}$ & 0 & 400 & 880 & Federal Repository & 2500 & 0 & 2000 & 4400 & $\begin{array}{l}\text { Cask, Tiedonms, dedicated } \\
\text { Fratcar }\end{array}$ \\
\hline & Noble Gases 11 & $\sigma^{5 \mathrm{kr} \text { Gas }}$ & 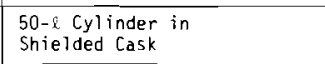 & 3 Cylinders/Cask & Rail & $6 \cos k 5$ & 0 & $\operatorname{MMT} T(m)$ & 3Мт & 0 & 2 & 6 & Federal Repository & 2500 & 0 & 10 & 30 & $\begin{array}{l}\text { Casks, Tiedoms, Dedicated } \\
\text { Flatcar }\end{array}$ \\
\hline & Tritium(1) & $\mathrm{Ca}(0 \mathrm{OT})_{2}$ & Stee\} Druns in Overpack & 2102 & Truck & 42 Drums in Overpack & 0 & $65 m^{3}(n)$ & $177 m^{3}$ & 0 & 7 & 20 & Burial Ground & 800 & 0 & 10 & 30 & Overpack \\
\hline & TRU Waste & \begin{tabular}{|l|l} 
Vari ious contaminated Sol ids \\
\end{tabular} & $\begin{array}{l}\text { Steel Drums. Plywood Boxes } \\
\text { some in protective overpacks }\end{array}$ & 210 & Rail & 140 oruns & 0 & $13,00 \mathrm{~m}^{3}$ & $30,000 m^{3(6)}$ & 0 & 450 & 1000 & Federal Repositary & 2500 & 0 & 1100 & 2500 & Overpack, (Some Shi prnents) \\
\hline & Non-Tru Waste & \begin{tabular}{|l} 
Various Contaminated Sol ids \\
\end{tabular} & 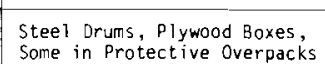 & 2102 & Rail & 140 oruss & 0 & $3,500 \mathrm{~m}^{3}$ & $7,800 \mathrm{~m}^{3}$ & 0 & 120 & 260 & Burial Ground & 800 & o & 100 & 200 & $\begin{array}{l}\text { Overpack, (Sone Shiprnents) } \\
\end{array}$ \\
\hline & Sli igntly Enriched $\mathrm{UF}_{6}$ & \begin{tabular}{|l} 
Volat ile Sol id \\
\end{tabular} & 14-Ton Cylinder & $12.7 \mathrm{MT}$ & Rail & 4 cylinders & 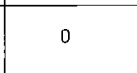 & $7,200 \mathrm{mT}$ & 17,000m & o & 140 & 330 & Enrichnent Plant & 800 & 0 & 220 & 530 & \begin{tabular}{|c|} 
cylinders, cradles, Tiedouns, \\
\end{tabular} \\
\hline
\end{tabular}

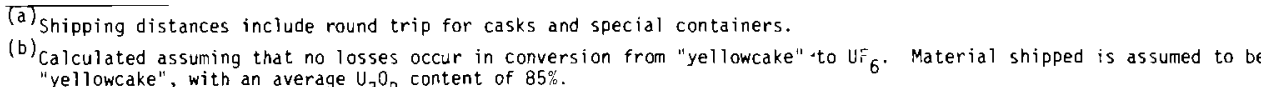
(c) Reference 21. An enrichment tails assay of $0.25 \%$ has been assumed.

e) huste vorumes based on information in Reference 22.

and depleted uranium dioxide.

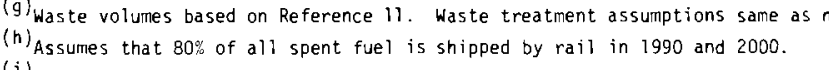

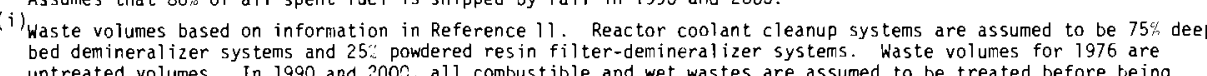

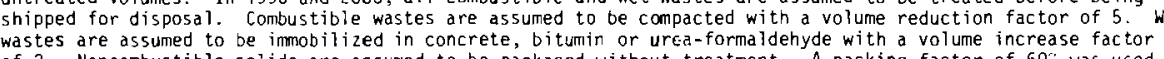

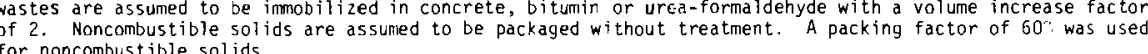

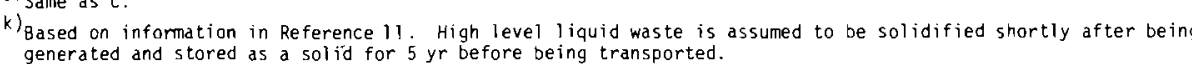
(1) collection and transportation of these naterials is not currently required. These naterials are included
because transsortation of these naterials may be reguired in the future.

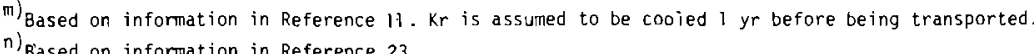

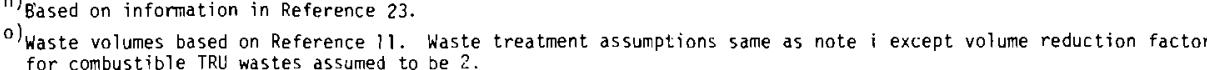


TABLE 2. Projected Growth of Nuclear Power

$\begin{array}{llrrr} & & \underline{1976} & \underline{1990} & \underline{2000} \\ \text { PWR } & \text { (GWe) } & 27 & 167 & 312 \\ \text { BWR } & \text { (GWe) } & 17 & 84 & 156 \\ \text { LMFBR } & \text { (GWe) } & - & \frac{1}{252} & \frac{32}{500}\end{array}$

Table 3 presents an estimate of the number of shipments of various types from typical fuel cycle facilities. These estimates assume that the fuel cycle as depicted in Figure 1 is fully operational in a relatively steady state. Waste shipments are based on the waste treatment assumptions for 1990 . 
TABLE 3. Estimated Annual Shipments from Typical Fuel Cycle Facilities (Steady State Fuel Cycle Operation)

\begin{tabular}{|c|c|}
\hline $\begin{array}{l}1000 \text { Mide } \\
\text { Light Water Reactor }\end{array}$ & Shipments/Yr \\
\hline Spent Fuel (Truck) & 5 \\
\hline (Rail) & 5 \\
\hline Waste (Truck) & $\underline{20}$ \\
\hline TOTAL & 30 \\
\hline \multicolumn{2}{|l|}{$\begin{array}{c}1500 \mathrm{MTHM} / \mathrm{yr} \\
\text { Reprocessing Plant }\end{array}$} \\
\hline Plutonium & 40 \\
\hline Solidified High Level Waste (Rail) & 20 \\
\hline Cladding Waste (Rail) & 100 \\
\hline Noble Gases (Rai1) & 1 \\
\hline Lodine (Truck) & 1 \\
\hline Tritium (Truck) & 2 \\
\hline TRU Waste (Rail) & 110 \\
\hline Non-TRU Waste (Rai1) & 30 \\
\hline$U F_{6}(14-T o n$ Cy 1 inder by Rail) & 30 \\
\hline TOTAL & 330 \\
\hline \multicolumn{2}{|l|}{$\begin{array}{l}1500 \mathrm{MTU} / \mathrm{yr} \\
\mathrm{UO}_{2} \text { Fuel Fabrication Plant }\end{array}$} \\
\hline Fresh Fue1 (Truck) & 260 \\
\hline Waste (Truck) & 90 \\
\hline TOTAL & 350 \\
\hline \multicolumn{2}{|l|}{$\begin{array}{l}300 \mathrm{MTHM} / \mathrm{yr} \\
\text { Mixed Oxide Fuel Fabrication Plant }\end{array}$} \\
\hline Fresh Fue? (Truck) & 50 \\
\hline Waste (Truck) & 50 \\
\hline TOTAL & 100 \\
\hline \multicolumn{2}{|l|}{$U_{\text {UF }} \begin{array}{c}15,000 \mathrm{MTU} / \mathrm{yr} \\
\text { Conversion Facility }\end{array}$} \\
\hline Natural $U_{6}(10-$ Ton Cylinders By Truck) & 900 \\
\hline Waste (Truck) & $\underline{220}$ \\
\hline TOTAL & 1120 \\
\hline \multicolumn{2}{|l|}{$\begin{array}{l}1800 \text { MT } \\
\text { Ore/day Uranium Mill }\end{array}$} \\
\hline$U_{3} O_{8}(\operatorname{Ra} i)$ & 30 \\
\hline \multicolumn{2}{|l|}{$\begin{array}{l}18.75 \mathrm{MT} \text { SWU/yr } \\
\text { Uranium Enrichment Plant }\end{array}$} \\
\hline Enriched UF 6 (2 1/2-Ton Cylinder by Truck) & 300 \\
\hline Waste (Truck) & 140 \\
\hline TOTAL & 440 \\
\hline
\end{tabular}




\section{REFERENCES}

1. Uranium Hexafluoride: Handling Procedures and Container Criteria. ORO-651, USAEC, Oak Ridge Operations Office, Oak Ridge, TN, August 1972.

2. Radioactive Materials Transportation Manual. Tri-State Motor Transit Co., Joplin, MO.

3. Photographs furnished by Sandia Laboratories, Albuquerque, NM.

4. J. J. Perona, R. S. Dillon and J. O. Blomeke, Design and Safety Considerations of Shipping Solidified High Level Radioactive Wastes. ORINL-TM-2971, Oak Ridge Nationa? Laboratory, Oak Ridge, TN, December 1970.

5. J. J. Perona and J.0. Blomeke, A Parametric Study of Shipping Casks for Solid Radioactive Wastes. ORNL-TM-3657, Oak Ridge National Laboratory, Oak Ridge, TN, February 1972.

6. W. V. Loscutoff and R. J. Ha11, "A Safety and Economic Study of Special Trains." Proceedings of the AIF Conference on Transportation for the Nuclear Industry, Minneapolis, MN, May 25-28, 1976.

7. P. L. Peterson, Conceptual Design of a Shipping Container for Transporting High-Level Radioactive Waste by Railroad. BNWL-2244, Battelle, Pacific Northwest Laboratories, Richland, WA (to be published).

8. R. E. Best and J. L. Ridihalgh, "The Development of a Packaging for the Transportation of Plutonium." in Proceedings of the Fourth International Symposium on the Packaging and Transportation of Radioactive Materials. CONF-740901, Miami Beach, FL, September, 1974.

9. J. 0. Blomeke, C. W. Kee and J. P. Nichols, Projection of Radioactive Wastes to be Generated by the U.S. Nuclear Power Industry. ORNL-TM-3965 Oak Ridge National Laboratory, Oak Ridge, TN, February 1974.

10. Title 10, Part 20, Code of Federal Regulations Proposed Rule Making, 39 Federal Register 30164, August 21, 1974.

11. M. J. Steindler et al., "LWR Fuel Cycle Waste," Alternatives for Managing Wastes from Reactors and Post-Fission Operations in the LWR Fuel Cycle, ERDA 76-43, United States Energy Research and Development Administration, Washington, DC, May 1976.

12. L. D. Williams et a1., "Transportation Alternatives," Alternatives for Managing Wastes from Reactors and Post-Fission Operations in the LWR Fuel Cycle, ERDA 76-43, United States Energy Research and Development Administration, Washington, DC, May 1976.

13. Environmental Radiation Dose Commitment: An Application to the Nuclear Power Industry, EPA-520/4-73-002, U.S. Environmental Protection Agency, Office of Radiation Programs, Washington, DC, February 1974. 
14. J. 0. Blomeke and J. J. Perona, Management of Noble Gas Fission Products from Reprocessing Spent Fuels, ORNL-TM-2677, Oak Ridge National Laboratory, Oak Ridge, TN, November 1969.

15. Elk River Reactor Dismantling Activity Specifications No. 10 - Material Disposa1, Gulf United Nuclear Fuels Corporation, Elmsford, NY, February 1972.

16. Directory of Packaging for the Transportation of Radioactive Materials, WASH-1279, USAEC Division of Waste Management and Transportation, Washington, DC, October 1973.

17. D. A. Edling and J. F. Griffin, Certification of ERDA Contractors Packaging with Respect to Compliance with DOT Specification 7A Performance Requirements (MLM 2228), Mound Laboratory, Miamisburg, $\overline{\mathrm{OH}}$, June 1975 .

18. F. E. Adcock, ATMX-600 Railcars for Radioactive Waste Shipments RFP-1411, The Dow Chemical Co., Rocky Flats Division, Golden, C0, January 1970.

19. P. T. Tuite, "Radwaste Shipments from Operating Stations, an Overview," in Proceedings of the Fourth International Symposium on Packaging and Transportation of Radioactive Materials, CONF-740901, Miami Beach, $\overline{F L}$, September 1974.

20. Photograph reproduced from literature provided by Chem-Nuclear Systems, Inc., Bellevue, WA.

21. E. J. Hanrahan, Office of Analysis, APEA, U.S. Energy Research and Development Administration, Memorandum to F. P. Baranowski, Division of Nuclear Fuel Cycle and Production, ANE, U.S. Energy Research and Development Administration, August 19, 1976.

22. Final Generic Environmental Statement on the Use of Recycle Plutonium in Mixed Oxide Fuel in Light Water Reactors, NUREG-0002, U.S. Nuclear Regulatory Commission, Washington, DC, August 1976.

23. J. 0. Blomeke, C. W. Kee and R. Salmon, "Shipment in the Nuclear Fuel Cycle Projected to the Year 2000". Nuclear News. 18(6):62-65. 
APPENDIX A

GOVERNMENT REGULATIONS PERTAINING TO THE TRANSPORTATION OF RADIOACTIVE MATERIALS 


\section{FEDERAL REGULATIONS}

Regulations governing the transportation of radioactive materials have been established to prevent the loss or dispersal of material during shipment and to insure the safety of the public and transportation workers. There is overlapping responsibility for regulating the safe transport of radioactive materials. Primary responsibility at the federal level for the safety of radioactive shipments lies with the Department of Transportation (DOT) Materials Transportation Bureau and the Nuclear Regulatory Commission (NRC). A "Memorandum of Understanding" between the two agencies was signed in 1966 and revised in 1973. (1) This memorandum calls for cooperation between DOT and NRC and delineates the responsibilities of each agency. DOT is responsible for promulgating and enforcing safety standards governing packaging and shipping containers and for the labeling, classification and marking of all packages. DOT also implements safety standards for the mechanical condition of carrier equipment and qualifications of carrier personnel. NRC develops performance standards for package designs and reviews package designs for Type $B$, fissile and large quantity packages (defined below). DOT requires NRC approval to use these packages. (2) The Federal Aviation Administration, the Interstate Commerce Commission, the Civil Aeronautics Board, the U.S. Coast Guard and state regulatory agencies also exercise some regulatory authority over the shipment of radioactive materials.

The transportation or packaging for transport of radioactive material is subject to issuance of the appropriate licenses. Applicants for a license to package or to transport radioactive material must show by a combination of analysis and experiment that the proposed package or transport vehicle satisfies all the requirements set forth in the Code of Federal Regulations. The application must describe proposed controls or precautions to be used in the loading, unloading, handling and transport of radioactive material and the procedures to be followed in the event of an accident or delay in shipment. Inspection and accountability procedures must also be described. 
The following Federal Regulations are applicable to the transportation of radioactive materials:

- Title 49 Code of Federal Regulations Parts 170-199 (49 CFR 170-199) Department of Transportation regulations governing the transport of hazardous materials.

- 10 CFR 71 - Nuclear Regulatory Commission regulations governing the packaging and shipment of radioactive materials.

- 14 CFR 103 - Federal Aviation Administration regulations for shipment of radioactive materials by air.

- 46 CFR 146 and 149 - U.S. Coast Guard regulations. governing the shipment of radioactive materials by water.

- 10 CFR 73 - NuClear Regulatory Commission regulations for the protection of special nuclear material in transit.

DOT and NRC regulations are the most important for shipments in the Nuclear Fuel Cycle. These regulations will be reviewed here.

Transport Group

Radioactive materials are classified for transportation purposes into one of seven transport groups according to their radiotoxicity and potential hazard if released to the environment. (a) Transport Group I is the most restrictive. Materials such as plutonium are placed in this group. Materials such as tritium gas with a relatively low hazard potential are placed in Transport Group VII.

\section{Quantity Designations}

A shipment of radioactive material is classified as Type A, Type B, or Large Quantity of Radioactive Material depending on the amount of radioactivity it contains. The dividing line between the quantity types is dependent on the Transport Group of the material being shipped. (See Table A-1.)

(a) It is anticipated that the U.S. Regulations will be changed in the near future to agree in substance with 1973 IAEA Regulations. The transport group designation has been replaced with a different system in these regulations. (See References 3 and 4.) 
If a shipment contains materials from more than one Transport Group, the most restrictive group will generally apply for the determination of quantity type. (See 10 CFR $71.4(p)$.)

TABLE A-1. Maximum Activities for Normal Form ${ }^{(a)}$ Type A and B Quantities of Radioactive Material by Transport Group

\begin{tabular}{lccc} 
Transport Group & Type A Quantity (Ci) & Type B Quantity (Ci) \\
\cline { 2 - 3 } I & 0.001 & 20 \\
II & 0.05 & 20 \\
III & 3 & 200 \\
IV & 20 & 200 \\
V & 20 & 5000 \\
VI and VII & 1000 & 50000
\end{tabular}

NOTE: Any quantity greater than Type $B$ is defined as a "Large Quantity" of radioactive material.

(a) Normal form material is everything that does not meet the "Special Form" criteria outlined below.

Low Specific Activity (LSA) Materials

Some shipments of material with a relatively low hazard potential are exempted from certain of the requirements in the regulations even though they may contain Type $A$ or $B$ quantities of radioactive materials. LSA materials include uranium or thorium ores, unirradiated depleted or natural uranium, unirradiated thorium; aqueous solutions of tritium oxide containing less than $5 \mathrm{mCi} / \mathrm{ml}$; and materials having uniformly distributed activity in which the concentrations per gram does not exceed the following:

- $0.1 \mu \mathrm{Ci}$ of Group I materials

- $5.0 \mu \mathrm{Ci}$ of Group II radionuclides

- $300 \mu \mathrm{Ci}$ of Group III and IV materials. 
Externally contaminated non-radioactive materials may be considered LSA provided the contamination is not readily dispersible and the average surface contamination per square centimeter does not exceed the following:

- $0.1 \mu \mathrm{Ci}$ for Group I radionuclides

- $1.0 \mu \mathrm{Ci}$ for other materials.

Special Form Material

Radioactive material in special form may be transported as if it were Transport Group $V$ regardless of the radioactive species present. Special form material meets one of the following criteria:

1. Radioactive material in solid form having no dimension less than $0.5 \mathrm{~mm}$ (or one dimension greater than $5 \mathrm{~mm}$ ). Will not sublime, melt or ignite in air at $538^{\circ} \mathrm{C}$. Remains nondispersible after immersion for one week in water at $20^{\circ} \mathrm{C}$ or air at $30^{\circ} \mathrm{C}$.

2. Radioactive material contained in a capsule that will satisfy the above requirements.

Special form material must remain intact after a test that includes a 9.1-m drop, impact of $1.4-\mathrm{Kg}$ steel rod dropped from a height of $1 \mathrm{~m}$, heating to $800^{\circ} \mathrm{C}$ for 10 minutes and immersion in water for 24 hours.

Fissile Classification

A shipment containing fissile materials $\left({ }^{233} \mathrm{U},{ }^{235} \mathrm{U},{ }^{238} \mathrm{Pu},{ }^{239} \mathrm{Pu},{ }^{241} \mathrm{Pu}\right)$ is classified according to the amount of control which must be exercised to prevent nuclear criticality in shipment.

- Fissile Class I packages may be shipped in unlimited numbers in any arrangement, requiring no nuclear criticality considerations.

- Fissile Class II packages may be shipped together in any arrangement but their numbers are limited to an aggregate Transport Index (see definition below) of 50 . For purposes of nuclear criticality safety, individual packages must have a transport index between 0.1 and 10 . 
- Fissile Class III packages must be controlled in transport by special arrangements between the shipper and the carrier to provide nuclear criticality safety.

Certain shipments of fissile materials are exempt from the normal requirements for packages containing fissile material. These packages meet one of the following criteria (among others - see 10 CFR 71.9):

1. Contain less than $15 \mathrm{~g}$ fissile material

2. Contain Th or $U$ with less than $0.72 \%$ fissile material

3. Contain less than $350 \mathrm{~g}$ fissile material with a maximum of $5 \mathrm{~g}$ in any 0.028 cubic meter $\left(1 \mathrm{ft}^{3}\right)$ of the package.

\section{Transport Index}

The transport index is a number placed on a package of radioactive material to designate the degree of control to be exercised by the carrier during transportation. The transport index is the larger of the following numbers:

1. The highest radiation dose rate in $\mathrm{millirem} / \mathrm{hr}$ at $1 \mathrm{~m}$ from any accessible external surface of the package; or

2. For Fissile Class II packages the number 50 divided by the maximum number of such packages which may be transported together with criticality safety considerations.

Except in a exclusive use vehicle, the aggregate transport index of all packages in any storage area during transportation must be exceed 50 . (Shipments of Fissile Class II packages can never exceed an aggregate transport index of 50. A total transport index of 100 is permitted for fissile Class III shipments.) The transport index also determines the labeling requirements for the package.

Special Nuclear Material (SNM)

A shipment of radioactive material is designated special nuclear material if it contains 5000 grams or more of ${ }^{235} \mathrm{U}$ (contained in uranium enriched to 20 percent or more), ${ }^{233} \mathrm{U}$ or plutonium or any combination of the three computed by the formula

$$
\text { grams }=\text { grams } 235 U+2.5(\text { grams } 233 U+\text { grams } P u) \text {. }
$$


10 CFR 73 requires that shipments of special nuclear material be afforded additional physical protection in transit to prevent theft or sabotage. These protective measures include:

- Carrier procedures NRC approved pre-planned

- Hand-to-hand receipts

- Tamper-indicating seals on all containers

- Minimum container weights of $227 \mathrm{~kg}$ for shipments in open vehicles

- No cargo transfers enroute

- Periodic radio communication between transport vehicle and carrier dispatcher

- Armed escorts or specially designed transport vehicles with disabling features

Radiation Dose Requirements

Radiation dose rates from shipments of radioactive materials are also limited by the regulations. Larger maximum radiation dose levels are allowed for vehicles being used exclusively to transport radioactive materials than for non-exclusive use vehicles. For vehicles not in exclusive use the following limits apply

- $200 \mathrm{millirem} / \mathrm{hr}$ at any point on the external surface of the package

- $10 \mathrm{millirem} / \mathrm{hr}$ at $1 \mathrm{~m}$ from the package

For vehicles being used exclusively for the transport of radioactive materials the limits are as follows:

- $1000 \mathrm{milli}$ rem/hr at $1 \mathrm{~m}$ from the external surface of the package (closed transport vehicle only)

- $200 \mathrm{millirem} / \mathrm{hr}$ at any point on the external surface of the vehicle (closed transport vehicle only)

- $10 \mathrm{milli}$ rem/hr at $2 \mathrm{~m}$ from the external surface of the vehicle

- 2 millirem/hr in any normally occupied position in the vehicle.

These dose linits are illustrated in Figure A-1 for truck transport. 


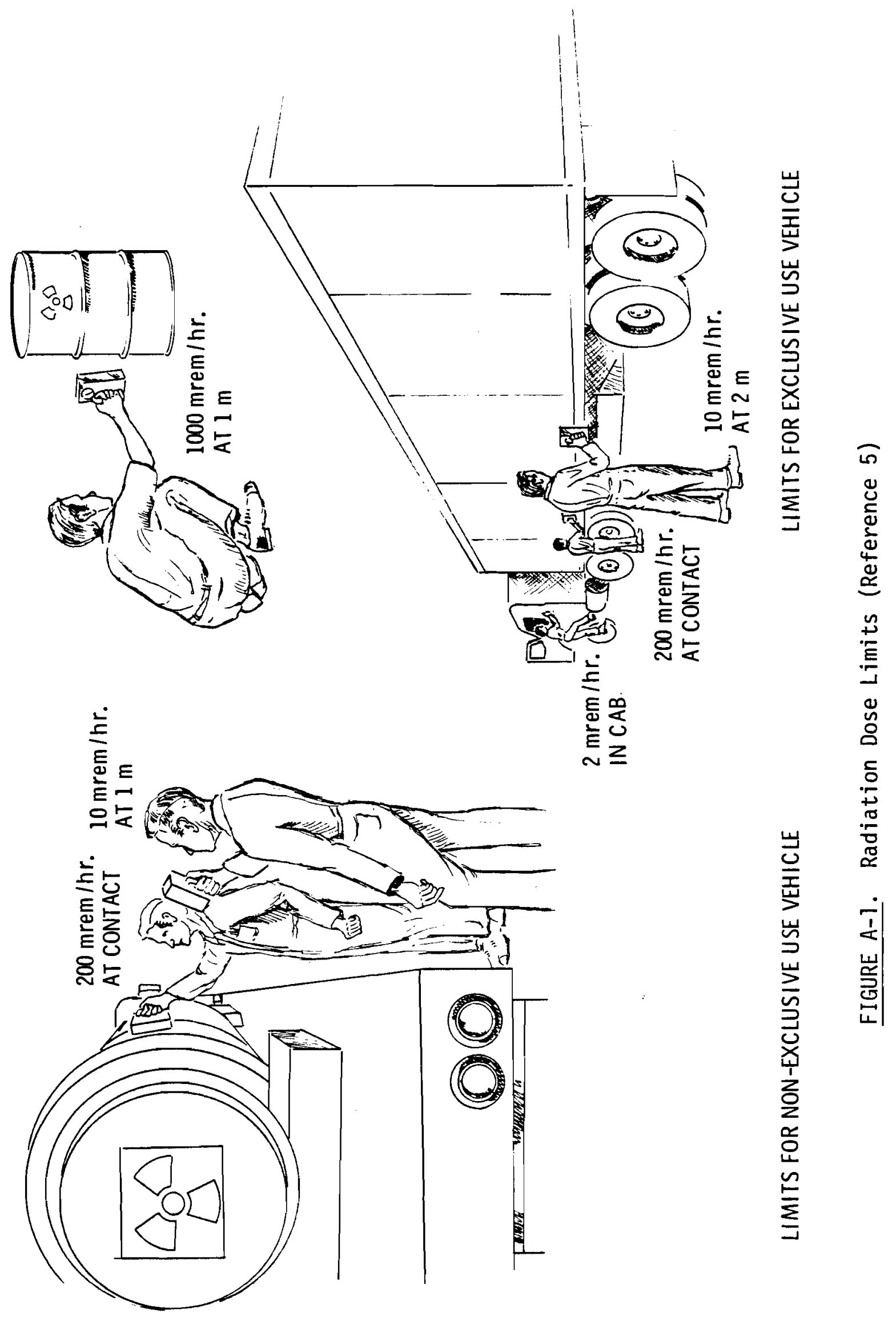




\section{Packaging}

The type of packaging required for a shipment of radioactive material is dependent on the type, quantity, form and fissile classification of the material to be shipped. 49 CFR allows shipment of radioactive materials in DOT specification containers, in containers licensed by NRC or in containers authorized by special permit from DOT. (a) The specification containers are described in the regulations. All radioactive material shipping containers must meet the general package requirements for radioactive material shipping containers 49 CFR 173.393 and the general requirements for a11 packaging used in interstate commerce contained in 49 CFR 173.24.

Low specific activity material shipped in exclusive use vehicles is exempt from most of the packaging requirements of 49 CFR. Basically only strong, tight packaging is required. The radiation dose limits discussed previously are still applicable, however.

Type A quantities of radioactive material must be shipped in DOT specification 6M packaging, approved Type B packaging or packaging that meets the requirements of DOT specification 7A (See 49 CFR 178.350). In addition to meeting the general packaging requirements of 49 CFR 173.24 and 49 CFR 173.393, specification 7A packaging must be capable of maintaining its shielding integrity and preventing the dispersal of its contents during a test simulating conditions normally incident to transportation. These test conditions are outlined below.

\section{Test Representing Conditions Normally Incident To Transportation}

- Heat - direct sunlight at an ambient temperature of $54^{\circ} \mathrm{C}$ in still air.

- Cold - an ambient temperature of $-40^{\circ} \mathrm{C}$ in still air and shade.

- Pressure - one half standard atmospheric pressure.

- Vibration - normally incident to transport.

(a) Special permits are no longer issued for radioactive material shipping containers. The special permits now in effect will be allowed to expire without renewal. In the future all radioactive material will be shipped in DOT specification or NRC licensed containers. 
- Water spray - sufficient to keep the exposed surfaces of the package except the bottom wet for 30 minutes.

- Free drop - $11 / 2$ to $21 / 2$ hours after the water spray test at a distance of 1.3 to $1.2 \mathrm{~m}$ (depending on package weight) onto an unyielding surface.

- Corner drop - onto each corner in succession (each quarter of each rim for cylinders) from a height of $30 \mathrm{~cm}$ onto an unyielding surface (applies only to wood or fiberboard containers of less than $45 \mathrm{~kg}$ and to all Fissile (lass II Packages).

- Penetration - impact of the hemispherical end of $5.9 \mathrm{~kg}$ steel cylinder $3.2 \mathrm{~cm}$ in diameter dropped from a height of $1 \mathrm{~m}$ onto the most vulnerable surface of the package.

- Compression - a compressive load against the top and bottom of the package in its normally transported condition. The load is the greater of 5 times the weight of the package or 1.38 neutrons/ $\mathrm{cm}^{2}$ times the minimum horizontal cross section of the package. (This test applied only to packages weighing less than $4535 \mathrm{~kg}$.)

Type $B$ quantities of radioactive material may be shipped in DOT specification 6M containers, in packaging authorized by NRC or in packaging meeting the 1973 IAEA requirements (provided DOT has validated the approval of the foreign competent authority). Type B packaging submitted to NRC for approval must be able to maintain its integrity through the test conditions outlined below simulating transportation accident environments as well as the test simulating conditions normally incident to transportation outlined above.

Test Conditions Simulating Severe Transportation Accident Environments (Tests applied sequentially to determine cumulative effect on the package.)

- Free drop - through a distance of $9.1 \mathrm{~m}$ onto an unyielding surface striking the surface in the position which would produce maximum damage. 
- Puncture - a free drop through a distance of $1 \mathrm{~m}$ onto a cylindrical steel bar $15.2 \mathrm{~cm}$ in diameter with the edge rounded to a radius of $6.4 \mathrm{~mm}$. The length of the bar is selected for maximum damage (minimum length is $20.3 \mathrm{~cm}$ ). The bar is mounted on an unyielding horizontal surface and the package is dropped in a position expected to produce maximum damage.

- Therma 1 - exposure to the equivalent of a $800^{\circ} \mathrm{C}$ fire for 30 minutes with no artificial cooling for $3 \mathrm{hrs}$ after the exposure.

- Water immersion - (fissile material packages only) at a depth of $91 \mathrm{~cm}$ for 8 hours.

Large quantities of radioactive materials are shipped in Type B packaging. The packaging used must provide adequate shielding and heat removal capabilities for the radioactive material to be transported.

Fissile material may be shipped in DOT specification 6L (Type A quantities only) or 6M packaging or in packaging approved by NRC. Packaging approved by NRC for fissile materials must meet some requirements not posed on containers for other radioactive materials (See 10 CFR 71.38 71.40). These conditions insure a wide margin of safety on the number of packages which can be shipped at one time. They also insure that a critical mass could not be assembled in the event of a transportation accident.

Special Regulations Applying to Plutonium

Because of its hazardous nature, there are some special regulations in effect for the shipment of plutonium. Plutonium may presently be shipped as a liquid (in nitrate solution) or as a solid (plutonium oxide). After June 1978, plutonium in excess of $20 \mathrm{Ci}$ per package must be shipped as a solid. (10 CFR 71.42). The plutonium must be double packaged and the inner container must maintain its containment integrity as the outer container undergoes the tests for Type B packaging. The separate outer container must meet the requirements for packaging of material in normal form. 
Federal regulations prohibit shipments of plutonium in passenger aircraft in quantities exceeding 20 grams or $20 \mathrm{Ci}$, whichever is less ( $10 \mathrm{CFR}$ 71.42). However, a recently enacted federal statute has placed an embargo on shipments of plutonium by air until it is shown that the shipping containers will not release their contents in an airplane crash environment.

State Regulations

Although federal agencies dominate the regulatory process for the transportation of radioactive materials, state governments also exercise some control over these shipments. State highway departments regulate gross vehicle weights, vehicular dimensions and other parameters for radioactive shipments just as they do for other kinds of shipments. About one half of the states have adopted the U.S. DOT Hazardous Materials Regulations to cover intra-state shipments. Several states have adopted or proposed additional regulations concerning radioactive materials. $(1,6)$ These include:

- Special routing of radioactive shipments

- Advance notification for shipments of large quantities of materials

- State inspections of some types of radioactive shipments

- Prohibition of certain types of shipments within the states

- Prior approval for radioactive shipments

- Requirement of exclusive use vehicle for radioactive shipments

- Use of pilot vehicles

- Speed restrictions for radioactive shipments

- Specific hours of movement

- Accompaniment of all shipments by radiation monitoring personnel. The variation of regulations between adjacent states can often require special considerations for interstate shipments. 
There is a potential conflict between some of the proposed state laws and the provisions of the National Transportation Act of 1974. (Public Law 93-633 signed in 1975). This law prohibits the states from adopting laws or regulations more stringent than Federal regulations unless the state regulations improve transportation safety. Even in this case, such rules can be adopted only if they do not unreasonably burden commerce. 


\section{REFERENCES}

(Transportation Regulations)

1. C. K. Beck, Intergovernmental Relationships in the Transport of Radioactive Materials," in Proceedings of the Second Arnual Legislative Workshop, (CONF-730588), Oak Ridge, TN, May 1973.

2. W. M. Rogers, Jr., "State and Federal Roles in Regulating the Transportation of Radioactive Materials," in Proceedings of the 4th International Symposium on Packaging and Transportation of Radioactive Material (CONF-740901), Miami Beach, FL, September 1974.

3. A. W. Grella, "An Update on the Status of Recent and Proposed Changes to the U.S. Regulations for Transport of Radioactive Material," in Proceedings of the 4th International Symposium on Packaging and Transportation of Radioactive Material, (CONF-740901), Miami Beach, FL, September 1974.

4. Regulation for the Safe Transport of Radioactive Materials 1973 Revised Edition, Internationa 1 Atomic Energy Agency, Vienna, Austria, 1973.

5. Radioactive Materials Transportation Manual, Nuclear Transport Division, Tri-State Motor Transit Co., Joplin, M0, 1974.

6. W. A. Brobst, "The State of State Regulations," in Proceedings of the 4th International Symposium on Packaging and Transportation of Radioactive Material (CONF-740901), Miami Beach, FL, September 1974.

\section{General References}

F. B. Conlon and G. L. Pettigrew, Summary of Federal Regulations for Packaging and Transportation of Radioactive Materials, (BRH/DMRE 71-1) U.S. Department of Health Education and Welfare Public Health Service, Bureau of Radiological Health, Rockville, MD, February 1971.

W. A. Brobst, Transportation of Nuclear Fuel and Waste, presented at Waste Management 1974 Symposium, Department of Nuclear Engineering, University of Arizona, Tucson, AZ, April 1974. 


\section{Distribution}

No. of

Copies

OFFSITE

A. A. Churm

ERDA Chicago Patent Group

Chicago Operations Office

9800 South Cass Avenue

Argonne, IL 60439

160 ERDA Technical Information Center

K. A. Trickett

ERDA Division of Reactor Development and Demonstration

USERDA Headquarters

Germantown, MD 20014

25 W. Brobst

ERDA Division of Environmental Control Technology

Transportation Branch

USERDA Headquarters

Washington, DC 20545

J. Counts

ERDA Division of Environmental Control Technology

Transportation Branch USERDA Headquarters

Washington, DC 20545

M. Chais

ERDA Division of Environmental Control Technology

Transportation Branch

USERDA Headquarters

Washington, DC 20545

R. Garrison

ERDA Division of Environmental

Control Technology

Transportation Branch

USERDA Headquarters

Washington, DC 20545
No. of

Copies

W. S. Holman

EROA Division of Environmental Control Technology

Transportation Branch

USERDA Headquarters

Washington, DC 20545

J. A. Sisler

ERDA Division of Environmental Control Technology

Transportation Branch

USERDA Headquarters

Washington, DC 20545

R. M. Moser

ERDA Chicago Operations Office

9800 South Cass Avenue

Argonne, IL 60439

W. G. O'Quinn

ERDA Savannah River Operations Office

P.0. Box A

Aiken, SC 29801

N. Stetson

ERDA Savannah River Operations Office

P.0. Box A

Aiken, SC 29801

L. L. Turner

ERDA Savannah River Operations Office

P.0. Box A

Aiken, SC 29801

D. Davis

ERDA Albuquerque Operations Office P.0. Box 5400

Albuquerque, NM 87115 
No. of

Copies

\section{OFFSITE}

J. A. Lamb

ERDA Oak Ridge Operations Office P.0. Box E

Oak Ridge, TN 37830

J. J. Schreiber

ERDA Oak Ridge Operations Office P.0. Box E

Oak Ridge, TN 37830

R. C. Dove

University of California

Los Alamos Scientific Laboratory

P. 0. Box 1663

Los Alamos, NM 87545

T. K. Keenan

University of California

Los Alamos Scientific Laboratory

P. 0. Box 1663

Los Alamos, NM 87545

T. A. Butler

University of California

Los Alamos Scientific Laboratory

P. 0. Box 1663

Los Alamos, NM 87545

W. C. Bright

ERDA Abuquerque Operations

Office

Rocky Flats Area Office

P. 0. Box 928

Golden, C0 80401

L. Benner

National Transportation

Safety Board

Washington, DC 20594

A. L. Schmieg

National Transportation

Safety Board

Washington, DC 20594

J. Power

Westinghouse Electric Corp.

P.0. Box 355

Pittsburgh, PA 15230
No. of

Copies

P. J. Eicker

Sandia Laboratories, Livermore

Livermore, CA 94550

J. W. Langhaar

E. I. Dupont de Nemours \& Company

Savannah River Plant

Aiken, SC 29801

J. Curtis

Department of Transportation

Materials Transportation Bureau

2100 Second St. S.W.

Washington, DC 20590

B. D. Devine

Department of Transportation

Materials Transportation Bureau

2100 Second St. S.W.

Washington, DC 20590

A. Grella

Department of Transportation

Materials Transportation Bureau

2100 Second St. S.W.

Washington, DC 20590

H. Thompson

Department of Transportation

Materials Transportation Bureau

2100 Second St. S.W.

Washington, DC 20590

W. Rowe

Environmental Protection Agency

401 M. Street

Washington, DC 20460

A. J. Nertney

Aerojet Nuclear Company

550 2nd St.

Idaho Falls, ID 83401 
No. of

Copies

\section{OFFSITE}

R. G. Bradley

ERDA Division of Nuclear Fuel

Cycle and Production

USERDA Headquarters

Germantown, MD 20014

C. Starr

Electrical Power Research Inst.

P. 0. Box 10412

Palo Alto, CA 94304

C. Comar

Electrical Power Research Inst. P.0. Box 10412

Palo Alto, CA 94304

E. Zebrowski

Electrical Power Research Inst.

P.0. Box 10412

Palo Alto, CA 94304

R. Williams

Electrical Power Research Inst.

P. 0. Box 10412

Palo Alto, CA 94304

Combustion Engineering, Inc.

Windsor, CT 06095

J. Desmond

Babcock \& Wilcox, Co.

P.0. Box 1260

Lynchburg, VA 24505

C. Woods

Babcock \& Wilcox Co.

P.0. Box 1260

Lynchburg, VA 24505

Prof. Norman C. Rasmussen

Massachusetts Institute of

Technology

Cambridge, MA 02139
No. of

Copies

L. Bonzon

Sandia Laboratories

P. 0. Box 5800

Albuquerque, NM 87115

J. K. Cole

Sandia Laboratories

P. 0. Box 5800

Albuquerque, NM 87115

J. T. Foley

Sandia Laboratories

P. 0. Box 5800

Albuquerque, NM 87115

J. Freedman

Sandia Laboratories

P. 0. Box 5800

Albuquerque, NM 87115

W. F. Hartmann

Sandia Laboratories

P. 0. Box 5800

Albuquerque, NM 87115

2 R. M. Jefferson

Sandia Laboratories

P. 0. Box 5800

Albuquerque, NM 87115

R. Luna

Sandia Laboratories

P. 0. Box 5800

Albuquerque, NM 87115

T. G. Priddy

Sandia Laboratories

P. 0. Box 5800

Albuquerque, NM 87115

A. W. Snyder

Sandia Laboratories

P. 0. Box 5800

Aibuquerque, NM 87115 
Ho. of

Copies

OFFSITE

R. Yoshimura

Sandia Laboratories

P. 0. Box 5800

Albuquerque, NM 87115

R. F. Barker

Nuclear Regulatory Commission

Washington, DC 20555

C. B. Bartlett

Nuclear Regulatory Commission Washington, DC 20555

S. H. Hanauer

Nuclear Regulatory Commission Washington, DC 20555

S. Levine

Nuclear Regulatory Commission Washington, DC 20555

R. B. Minogue

Nuclear Regulatory Commission

Washington, DC 20555

C. McDonald

Nuclear Regulatory Commission

Washington, DC 20555

W. E. Vesely

Nuclear Regulatory Commission

Washington, DC 20555

I. Wa 11

Nuclear Regulatory Commission

Washington, DC 20555

M. J. Steindler

Argonne National Laboratory

9700 South Cass Avenue

Argonne, IL 60439

S. J. Basham

Battelle Memorial Institute

Columbus Operations

505 King Avenue

Columbus, $\mathrm{OH} 43201$
No. of

Copies

E. S. Cheaney

Battelle Memorial Institute

Columbus Operations

505 King Avenue

Columbus, $\mathrm{OH} 43201$

C. W. Hamilton

Battelle Memorial Institute

Columbus Operations

505 King Avenue

Columbus, $\mathrm{OH} 43201$

C. C. Kimm

Battelle Memorial Institute

Columbus Operations

505 King Avenue

Columbus, $\mathrm{OH} 43201$

R. D. King

Battelle Memorial Institute

Columbus Operations

505 King Avenue

Columbus, $\mathrm{OH} 43201$

E. C. Lusk

Battelle Memorial Institute

Columbus Operations

505 King Avenue

Columbus, $\mathrm{OH} 43201$

E. E. Rice

Battelle Memorial Institute

Columbus Operations

505 King Avenue

Columbus, $\mathrm{OH} 43201$

R. A. Robinson

Battelle Memorial Institute

Columbus Operations

505 King Avenue

Columbus, $\mathrm{OH} 43201$

R. W. Sullivan

Battelle Memorial Institute

Columbus Operations

505 King Avenue

Columbus, $\mathrm{OH} 43201$ 
No. of

Copies

OFFSITE

T. B. Allison

Staff, U.S. Senate Commerce

Committee

128 Russe 11

Senate Office Building

Washington, DC 20510

C. D. Brennan

Consultant

$487 \mathrm{~N}$. Owen St.

Alexandria, VA 22304

D. Capelle

Allan M. Voorhees \& Associates

1100 Glendon Ave.

Los Angeles, CA 90024

H. Wickman

Burl ington Northern

800 Central Building

Seattle, WA 98104

G. C. Loud

Tri-State Motor Transit Co.

P. 0. Box 113

Joplin, MD 64801

E. 0. Rutenkruger

Tri-State Motor Transit Co.

P. 0. Box 113

Joplin, MO 64801

W. L. Goodwin

Manager, R\&E Services

Westinghouse Nuclear Fuels

Division

P.0. Drawer $R$

Columbia, SC 29250

Atomics International

8900 DeSoto Avenue

Conoga Park, CA 91304

J. Buck

Nuclear Fuel Services

Irwin, TN 37650
No. of

Copies

A. L. Kaplan

General Electric Co.

Nuclear Fuel Division

P. 0. Box 780

Wilmington, NC 28401

G. Lapier

Babcock \& Wilcox Co.

Apo 110, PA 15613

J. G. Crawford

Goodyear Atomic Corp.

P. 0. Box 628

Piketon, $\mathrm{OH} 45661$

D. Pence

General Atomic

P. 0. Box 92138

San Diego, CA 92138

J. 0. Blomeke

Union Carbide Corporation

Oak Ridge National Laboratories

P. 0. Box $X$

Oak Ridge, TN 37830

R. D. Seagren

Union Carbide Corporation

Oak Ridge National Laboratories

P. 0. Box $X$

Oak Ridge, TN 37830

4 L. Shappert

Union Carbide Corporation

Oak Ridge National Laboratories

P. 0. Box $X$

Dak Ridge, TN 37830

J. Duckworth

Nuclear Fuel Service, Inc.

P. 0. Box 124

West Valley, NY 14171

W. A. 01dham

Nuclear Fuel Service, Inc.

P. 0. Box 124

West Valley, NY 14171 
No. of

Copies

OFFSITE

G. L Stukenbroeker

$\mathrm{N} L$ Industries, Inc.

Nuclear Transportation Dept.

919 Market St., Suite 1701

Wilmington, DE 19801

H. G. Shealy

Bureau of Radiological Health

South Carolina Department of

Health and Environmental

Control

Columbia, SC 29405

J. R. Ledford

Home Transportation Co.

P. 0. Box 1169

Barnwe11, SC 29812

J. S. Corbett

ChemNuclear Systems, Inc.

P. 0. Box 1866

Bellevue, WA 98009

J. A. Hebert

Battelle Seattle Research

Center

P. 0. Box 5395

Seattle, WA 98105

P. T. Tuite

Hittman Nuclear and Development Corporation

9190 Red Branch Rd.

Columbia, MD 21045

S. Williamson

Nuclear Engineering Co.

P.0. Box 4308

Walnut Creek, CA 94596

B. Jody, Jr.

Davis Transport

1345 S. 4th St.

Paducah, KY 42001
No. of

Copies

J. D. Lowe

Superior Trucking Co.

P. 0. Box 916

Atlanta, GA 30301

J. Edlow

Edlow International Inc.

1100 17th St. N.W., Suite 404

Washington, DC 20036

L. Rutland

ATCOR, Inc

Park Mal1

Peekski11, NY 10566

D. A. Edling

Mound Laboratories

P. 0. Box 32

Miamisburg, $\mathrm{OH} 45342$

J. W. Doty

Mound Laboratories

P. 0. Box 32

Miamisburg, $\mathrm{OH} 45342$

K. Gablin

Protective Packaging, Inc.

328 Production CT

Jefferson, KY 40299

D. Okrent

Department of Engineering and Applied Science

University of California

Los Angeles, CA 90024

2 L. Forrest

California Energy Resources Conservation and Development Commission

1111 Howe Avenue

Sacramento, CA 95825

M. Gordon

Atomic Industrial Forum

7101 Wisconsin Ave.

Washington, DC 20014 
No. of

Copies

$\underline{\text { OFFSITE }}$

A. L. Babb

Department of Nuclear Engineering Benson $\mathrm{Ha} 11$

University of Washington

Seattle, WA 98195

W. S. Fellows

Southern Interstate Nuclear Board

7 Dunwoody Park, Suite 104

Atlanta, GA 30341

J. Sawyer

McCormack's Highway Transport

Box 4, RD 3

Cambel1 Rd.

Schenectady, NY 12306

R. M. Graziano

Association of American

Railroads

1920 L St.

Washington, DC 20036

C. P. Furber

Association of American Railroads

1920 L. St.

Washington, DC 20036

Dr. F. Rieke

Industrial $\mathrm{Cl}$ inics

1313 NW 19th Ave.

Portland, OR 97209

D. G. Maxwe11

N. L. Industries

Nuclear Division

111 Broadway

New York, NY 10006

W. J. Burns

Department of Transportation

Office of Safety Affairs

2100 Second St. S.W.

Washington, DC 20590
No. of

Copies

N. Daramstadter

American Trucking Association 1616 P St. NW

Washington, DC 20036

A. French

Department of Transportation Federal Highway Administration 2100 Second St. N.W.

Washington, DC 20590

D. Goodman

Department of Transportation Federal Highway Administration 2100 Second St. N.W.

Washington, DC 20590

A. Clary

National Academy of Sciences

Transportation Research Board

2108 Constitution Avenue

Washington, DC 20418

W. R. Teer

Transnuclear Inc.

One N. Broadway

White Plains, NY 10601

S. Hartwig

Battelle Institute, e.v.

Am Romerhof 35

600 Frankfurt Main 90

GERMANY

M. Stammler

Battelle Institute, e.v.

Am Romerhof 35

600 Frankfurt Main 90

GERMANY

R. S. Lowrie

Union Carbide Corporation

Office of Waste Isolation

P. 0. BoX Y

Oak Ridge, TN 37830

D. Turner

Union Carbide Corporation

Office of Waste Isolation

P. 0. Box $Y$

Oak Ridge, TN 37830 
No. of

Copies

OFFSITE

S. C. Cohn

Teknekron

4701 Sangamore Rd.

Washington, DC 20016

G. H. Kimmons

Tennessee Valley Authority

New Sprankle Bldg.

Knoxville, TN 37902

W. A. Greten

Connecticut Yankee Atomic

Power Co.

107 Selden St.

Berlin, CT 06037

C. F. Whitmer

Georgia Power Co.

270 Peachtree St.

Atlanta, GA 30303

L. Liu

Iowa Electric Light and Power Co.

200 First St.

Cedar Rapids, IA 52401

L. L. Shepard

Consumers Power Co.

212 W. Michigan Ave.

Jackson, MI 49201

L. G. Wachter

Northern States Power Co.

414 Nicollet Mall

Minneapolis, Miv 55401

L. C. Shalla

Omaha Public Power District

1623 Harney St.

Omaha, NB 68102

J. W. Boston

Power Authority of the

State of New York

10 Columbus Circle

New York, NY 10019
No. of

Copies

H. G. Saddock

Rochester Gas \& Electric

Corp.

89 East Avenue

Rochester, NY 14649

J. A. Jones

Carolina Power \& Light Co.

336 Fayette St.

Raleigh, NC 27602

W. G. Dempler

Duquesne Light Co.

435 Sixth Ave.

Pittsburgh, PA 15219

J. S. Bartman

Metropolitan Edison Co.

2800 Pottsville Pike

Muhlenberg Township,

Berks County

P. 0. Box 542

Reading, PA 19603

R. S. Taltom

Carolina Power \& Light Co.

336 Fayette St.

Raleigh, NC 27602

E. B. Crutchfield

Virginia Electric and

Power Co.

700 East Franklin St.

Richmond, VA 23261

N. W. Moser

Dairlyand Power Cooperative

2615 E Ave. S.

La Crosse, WI 54601

W. Cavenaugh

Arkansas Power \& Light Co. P. 0. Box 551

Little Rock, AR 72203 
No. of

Copies

OFFSITE

D. V. Kelly

Pacific Gas and Electric Co. 77 Beale St.

San Francisco, CA 94106

D. C. Browning

Sacramento Municipa 1

Utility District

6201 S. Street

P. 0. Box 15830

Sacramento, CA 95813

L. T. Papay

Southern California Edison Co.

P. 0. Box 800

Rosemead, CA 91770

R. E. Uhrig

Florida Power \& Light Co.

9250 Flagler St.

Miami, FL 33174

F. A. Palmer

Cormmonwealth Edison Co.

P. 0. Box 767

Chicago, IL 60690

W. H. Dunham

Ma ine Yankee Atomic Power Co.

9 Green St.

Augusta, ME 04330

C. H. Poindexter

Baltimore Gas \& Electric Co. Gas \& Electric Bldg.

Baltimore, MD 21203

A. F. Corry

Boston Edison Co.

800 Boylston St.

Boston, MA 02199
No. of

Copies

D. G. Allen

Yankee Atomic Electric Co.

Turnpike Road

Route 9

Westboro, MA 01581

R. W. Berner

Nebraska Public Power District 2504 14th St.

Columbus, NB 68601

D. Ross

Jersey Central Power \&

Light Co.

Madison Ave. at Punch Bowl Rd.

Morristown, NJ 07960

S. A. Mallard

Public Service Electric \& Gas Co.

80 Park Place

Newark, NJ 07101

A. Hauspurg

Consolidated Edison Co. of N.Y. Inc.

4 Irving Place

New York, NY 10003

T. J. Brosnan

Niagara Mohawk Power Corp.

300 Erie Blvd. W.

Syracuse, NY 13202

D. J. Broeh1

Portland General Electric Co. 621 S. W. Alder St.

Portland, OR 97205

v. S. Boyer

Philadelphia Electric Co.

2301 Market St.

Philadelphia, PA 19101 
No. of

Copies

OFFSITE

S. K. Blackley

Duke Power Company

422 South Church St.

Charlotte, NC 28242

H. J. Van Groll

Wisconsin Public Service

Corp.

700 N. Adams St.

Green Bay, WI 54301

S. Burstein

Wisconsin Michigan Power Co.

807 South Oneida St.

Appleton, WI 54911

E. F. Wild Fong

Regulation and Research

Portland General Electric Co.

621 S.W. Alder St.

Portland, OR 97205

D. J. Broeh1

Regulation and Research

Portland General Electric Co.

621 S. W. Alder St.

Portland, OR 97205

R. V. Hugo

Public Service Co. of Colorado

550 15th St.

Denver, CO 80202

D. C. Cook

Indiana \& Michigan Power Co.

P. 0. Box 458

Bridgman, MI 49106

B. J. Garrick

Pickard, Low and Garrick, Inc.

200 Newport Center Drive

Suite 312

Newport Beach, CA 92660
No. of

Copies

I. N. Lafontaine

Belgonucleaire

Rue du Champ de Mars 25

B-1050 Bruxelles

BELGIUM

K. R. Shultz

Atomic Energy Control Board

P.0.B. 1046

0ttawa KIP $5 S 9$

CANADA

W. R. Taylor

Atomic Energy of Canada Ltd.

Chalk River Laboratories

Chalk River, Ontario KOJIJO

CANADA

Y. Sousselier

CEA/CEN

B.P. No. 6

F-92260 Fontenay-aux-Roses

FRANCE

H. Hubner

Bundesanstalt für Materialprufung

Unter den Eichen 87

D-1000 Berlin 45 (West)

GERMANY, FED. REPUBLIC

B. Schulz-Forberg

Bundesanstalt für Materialprufung

Unter den Eichen 87

D-1000 Berlin 45 (West)

GERMANY, FED. REPUBLIC

R. G. Deshpande

Isotope Division

Bhabha Atomic Research Centre

Trombay, Bombay 400085

INDIA 
No. of

Copies

OFFSITE

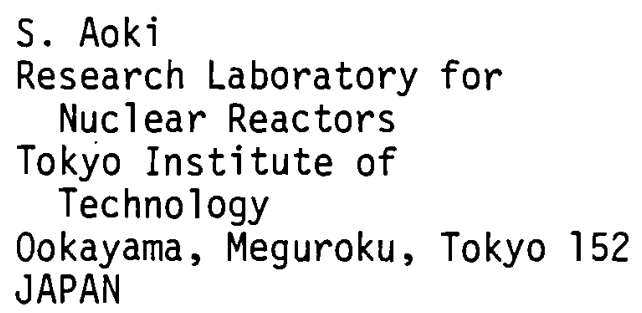

G. D. Bell

United Kingdom Atomic Energy Authority

Safety and Reliability

Directorate

Warrington WA3 4NE

UNITED KINGDOM

\section{A. Onedera \\ Hitachi Shipbuilding and \\ Engineering Co., Ltd. \\ 5-4 Sakurajima, Kitano-cho \\ Konohana-ku, Osaka-shi \\ JAPAN \\ K. Ikeda \\ Science and Technology Agency \\ 2-2-1 Kasumigaseki, \\ Chiyoda-ku, Tokyo \\ JAPAN \\ M. Toml inson \\ White Shell Nuclear Research \\ Establ ishment}

Pinewa, Manitoba ROE ILO

CANADA

S. A. Mayman

Fuel Recycle Waste

Management Program

Whiteshel1 Nuclear Research

Establ ishment

Pinewa, Manitoba ROE ILO

CANADA
No. of

Copies

Dr. F. Girardi

Euratom

21020 Centro Euratomdi

Ispra (Varesse)

ITALY

Ake Hultren

AB Atomenergi, Studsvik

Fack

S-611 ol Nyköping 1

SWEDEN

B. Gustafson

C/O Ake Hultgren

AB Atomenergi, Studsvik

Fack

S-611 ol Nyköping 1

SWEDEN

Dr. Schmidt-Kuester

Beim Bundesminister fur

Forschung and Technologie

Stresemannstrasse 2

5300 Bonn

GERMANY

Dr. R. E. Scott, Director University of Michigan Highway Safety Research Institute Huron Parkway and Baxter Road

Ann Arbor, MI 48105

W. J. Shel ley

Kerr-McGee Corporation

Oklahoma City, OK

R. W. Peterson

Allied General Nuclear Services

P. 0. Box 847

Barnwel1, SC 29812

A. Carson

General Electric Company

175 Curtner Avenue

San Jose, CA 95125 
No. of

Copies

\section{OFFSITE}

R. A. Koynenburg

University of California

Lawrence Livermore Laboratories

P. 0. Box 808

Livermore, CA 94551

W. E. Pollock

Oregon Department of Energy

Salem, OR 97301

K. Woods

Oregon Department of Energy

Salem, OR 97301

W. M. Rogers

Western Interstate Nuclear

Board

1300 Carr

Denver, CO 80226

G. P. Jones

University of Southern

California

University Park

Los Angeles, CA 90007

L. L. Philipson

University of Southern

California

University Park

Los Angeles, CA 90007

C. V. Hodges

Holmes \& Narver

400 E. Orangethrope Ave.

Anaheim, CA 92801

E. A. Straker

Science Applications, Inc.

P. 0. Box 2351

La Jolla, CA 92038

R. C. Erdman

Science Applications, Inc.

2680 Hanover St.

Palo Alto, CA 94304
No. of

Copies

G. Waymire

Exxon Nuclear Company, Inc.

P. 0. Box 3990

MS 8A-68

Seattle, WA 98124

\section{ONSITE}

1 ERDA Richland Operations Office Programs Division

H. E. Ranson

6 ERDA Richland Operations office

T. A. Bauman

W. A. Burns

R. B. Goranson

P. E. Lamont

J. M. Peterson

D. J. Squires

5 Atlantic Richfield Hanford Company

W. G. Bevan

R. E. Cross

D. Grudin

W. M. Harty

D. D. Woodrich

4 United Nuclear Industries, Inc.

J. A. Adams

P. A. Crosetti

T. E. Dabrowski

J. F. Nemec

2 Washington Public Power Supply System

G. F. Bailey

J. B. Vetrano

2 Exxon Nuclear Company, Inc.

$$
\text { R. Nilsen }
$$

R. K. Robinson 
No. of

Copies

ONSITE

Hanford Engineering Development

Laboratory

A. W. DeMerschman

Battelle-Northwest

W. B. Andrews

W. J. Bair

C. L. Brown

S. H. Bush

N. E. Carter

J. G. DeSteese

H. K. Elder

E. A. Eschbach

L. G. Faust

R. M. Fleischman

M. D. Freshley

J. Greenborg

R. J. Hall

H. Harty

S. W. Heaberlin

P. L. Hendrickson

H. L. Henry

J. F. Johnson

W. S. Kelley

S. N. Liu

W. V. Locustoff

T. I. McSweeney

J. Mishima

E. S. Murphy

P. L. Peterson

R. E. Rhoads

E. C. Watson

R. D. Widrig

L. D. Williams

W. K. Winegardner

C. L. Wilson

G. H. Winsor

Technical Information (3)

Technical Publications 